\title{
Research Paper \\ The Impact of Stress Inoculation Training on Cognitive Emotion Regulation and Psychological Problems of the Mothers of Blind Children
}

\author{
Ehsan Bahramfar ${ }^{1}$, Mohammad Ashori*2 \\ 1. M.A. Student in Psychology and Education of People with Special Needs, Faculty of Education and Psychology, University of \\ Isfahan, Iran
}

2. Assistant Professor, Department of Psychology and Education of People with Special Needs, Faculty of Education and Psychology, University of Isfahan, Iran

Citation: Bahramfar E, Ashori M. The impact of stress inoculation training on cognitive emotion regulation and psychological problems of the mothers of blind children. J Child Ment Health. 2021; 8 (1):27-42.

URL: http://childmentalhealth.ir/article-1-793-en.html
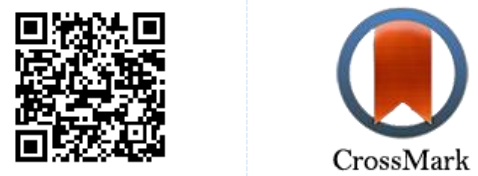

$10.52547 / \mathrm{jcmh} \cdot 8.1 .4$ 0.1001.1.24233552.1400.8.1.1.0
Open

Access

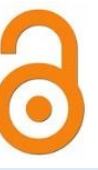

A R T I C L E I N F O

\section{Keywords:}

Stress inoculation, cognitive emotion regulation, blind children

Received: 18 Mar 2019 Accepted: 7 July 20219 Available: 29 May 2021

\section{A B S T R A C T}

Background and Purpose: Mothers of blind children have difficulty regulating emotions and psychological reactions. Stress inoculation training (SIT) seems to be advantageous for them. This study aimed to investigate the effect of stress inoculation on cognitive emotion regulation and psychological problems of mothers of blind children.

Method: The present research is a quasi-experimental study with a pretest-posttest design and control group. The study population included mothers of blind children aged 7-10 years in Isfahan city in 2018-2019. The participants were selected by convenient sampling method from Shahid Samani and Shahid Abedi schools and randomly divided into two experimental $(\mathrm{N}=17)$ and control $(\mathrm{N}=17)$ groups. The experimental group received the intervention in ten 45 -minutes sessions, but the control group did not receive any training. The instruments used were the Cognitive Emotion Regulation Questionnaire (Garnefski \& Kraaij, 2006) and the Depression, Anxiety, and Stress Scale (Lawibund \& Lawibund, 1995). Data were analyzed by MANOVA in SPSS.

Results: The results indicated that SIT had a significant impact on the adaptive strategies of cognitive emotion regulation in the participants $(\mathrm{F}=6.91, \mathrm{P}=0.01)$, but it had not a significant effect on their maladaptive strategies $(\mathrm{F}=0.19, \mathrm{P}=0.66)$. Moreover, the program had a significant impact on depression $(\mathrm{F}=22.42, \mathrm{P}=0.0001)$ and stress $(\mathrm{F}=10.99, \mathrm{P}=0.002)$ of participants, but there was no significant impact on their anxiety $(\mathrm{F}=0.19, \mathrm{P}=0.66)$.

Conclusion: The SIT affects emotional experiences and psychological reactions; therefore, it plays a crucial role in improving the emotion regulation and psychological problems of mothers of blind children.

* Corresponding author: Mohammad Ashori, Assistant Professor, Department of Psychology and Education of People with Special Needs,

Faculty of Education and Psychology, University of Isfahan, Iran.

E-mail: M.ashori@edu.ui.ac.ir

Tel: (+98) 3137935548

2476-5740/ (C) 2021 The Authors. This is an open access article under the CC BY-NC-ND license

(https://creativecommons.org/licenses/by-nc-nd/4.0/). 


\section{Extended Abstract}

\section{Introduction}

Family members of people with visual impairments may experience major psychological and emotional problems (1-3). The prevalence of visual impairment is about 0.04 percent (4). Visual impairment affects the perception of blind people (5), and their parents seem to face challenges in cognitive emotion regulation and experience psychological problems such as depression, anxiety, and stress (4). Emotions regulate through intrapersonal and interpersonal processes (6-8). Psychological problems also have different dimensions (12). Depression is one of the most common psychiatric disorders called mental cold (13). There are several associated factors with depression that anxiety and stress are the most important underlying factors (15). The experiencing of anxiety is also common in various periods of lifespan $(16,17)$. As a result of conflict between the individual and its environment, stress is also a condition that arises (18).

Stress inoculation training (SIT) is a program based on the cognitive-behavioral movement that improves emotion regulation and psychological problems (21, 22). This program combines techniques of cognitive reconstruction, problem-solving, stress relief, mental visualization, role-playing, self-instruction, and selfreinforcement $(23,24)$. The findings of some studies indicate the effect of SIT on improving depression, anxiety, and stress (28-26), and emotional problems (22), while the results of a study showed this program had no significant effect on the participants' stress (22).

The mothers of blind children have difficulty in emotion regulation which sometimes, leads to depression, anxiety, and stress. It seems that SIT can reduce emotional and psychological problems in different people. Therefore, the present study aimed to investigate the effect of SIT on cognitive emotion regulation and psychological issues of the mothers of blind children.

\section{Method}

This research was a semi-experimental study with the pretest-posttest and control group. The study population includes mothers of blind children aged 7-10 years during 2018-2019 in Isfahan City. Thirtyfour participants were selected with the convenient sampling method from Shahid Samani and Shahid Abedi schools and were randomly assigned into two experimental and control groups. Each group consisted of 17 individuals. The experimental group received ten sessions (two sessions weekly; each last for 45 minutes) of SIT, while the control group did not. The instruments of this research were the Cognitive Emotion Regulation Questionnaire (Garnefski \& Kraaij, 2006) and the Depression, Anxiety, and Stress Scale (Lawibund \& Lawibund, 1995). The SIT was taught to the experimental group using lectures, explanations, and role-playing methods. This program included concepts such as stress, positive mental imagery, relaxation and detensioning, cognitive reconstruction, spontaneous thoughts, cognitive errors, coping skills, guided selftalk, concentration, time management, social problem solving, self-regulation, and self-efficacy.

For conducting research was received a letter from the organization of management for exceptional education in Isfahan and coordinated with the schools' managers. The study purposes were explained to the participants by researchers in the first stage of the study; the participants completed an informed consent to participate in the research. The Cognitive Emotion Regulation Questionnaire and the Depression, Anxiety, and Stress Scale were used as a pretest to the assessment of cognitive emotion regulation and the depression, anxiety, and stress of participants, respectively. In the next stage, the SIT was implemented for the experimental group. After the intervention, the study groups were reassessed with previous questionnaires. The multivariate analysis of variance (MANOVA) was used for analyzing the data.

\section{Results}

Descriptive indicators of cognitive emotion regulation (adaptive and maladaptive strategies) and psychological problems (depression, anxiety, and stress) for the experimental and control groups in the pretest and posttest are showed in Table 1. 
Table 1. Descriptive indicators of cognitive emotion regulation and psychological problems

\begin{tabular}{|c|c|c|c|c|c|}
\hline \multirow{2}{*}{ Variables } & \multirow{2}{*}{ Test } & \multicolumn{2}{|c|}{ Experimental group } & \multicolumn{2}{|c|}{ Control group } \\
\hline & & $\mathbf{M}$ & SD & $\mathbf{M}$ & SD \\
\hline \multirow{2}{*}{ Adaptive strategies } & Pretest & 2.58 & 1.41 & 2.82 & 1.42 \\
\hline & Posttest & 3.52 & 1.41 & 2.74 & 1.48 \\
\hline \multirow{2}{*}{ Maladaptive strategies } & Pretest & 3.58 & 1.06 & 3.52 & 1.12 \\
\hline & Posttest & 2.58 & 1.54 & 3.47 & 1.12 \\
\hline \multirow{2}{*}{ Depression } & Pretest & 18.64 & 1.11 & 18.88 & 0.92 \\
\hline & Posttest & 15.94 & 1.24 & 18.58 & 1.06 \\
\hline \multirow{2}{*}{ Anxiety } & Pretest & 14.47 & 1.23 & 14.41 & 1.06 \\
\hline & Posttest & 12.29 & 1.53 & 14.35 & 1.61 \\
\hline \multirow{2}{*}{ Stress } & Pretest & 17.05 & 1.43 & 16.94 & 1.47 \\
\hline & Posttest & 14.29 & 1.86 & 17.11 & 1.36 \\
\hline
\end{tabular}

Table 1 displays the means and standard deviations of research variables. The normality of variables, contingency of variances, and variance-covariance equality was confirmed, but the slope of regression among variables was not confirmed $(\mathrm{P}<0.05)$. According to these reasons, two MANOVAs were run. The results of Roy's largest root test indicated that the experimental and control groups had a significant difference in subscales of cognitive emotion regulation (adaptive and maladaptive strategies) and psychological problems (depression, anxiety, and stress) $(\mathrm{P}<0.05)$. To find these differences, two MANOVA had run whose separated results are present in Table 2 and 3.

Table 2. MANOVA separated results for subscales of cognitive emotion regulation

\begin{tabular}{cccccccc}
\hline Dependent variables & Sum of squares & df & Mean square & F ratio & Sig. & Eta square & Test power \\
\hline adaptive strategies & 3.55 & 1 & 3.55 & 6.91 & 0.01 & 0.17 & 0.72 \\
maladaptive strategies & 0.11 & 1 & 0.11 & 0.19 & 0.66 & 0.06 & 0.07 \\
\hline
\end{tabular}

According to the results of table 2, the SIT had a significant impact on scores of the adaptive strategies of cognitive emotion regulation among participants ( $\mathrm{F}=6.91, \mathrm{P}=0.01$ ); but did not have a significant impact on their maladaptive strategies scores
$(\mathrm{F}=0.19, \mathrm{P}=0.66)$. Eta square coefficients indicated that 17 percent of the variation in the adaptive strategies of cognitive emotion regulation was due to the intervention impact.

Table 3. MANOVA separated results for subscales of psychological problems

\begin{tabular}{ccccccccc}
\hline Variables & Sum of squares & df & Mean square & F & Sig. & Eta square & Test power \\
\hline Depression & 36.02 & 1 & 36.02 & 22.42 & 0.0001 & 0.41 & 0.99 & 0.10 \\
Anxiety & 4.97 & 1 & 4.97 & 2.71 & 0.07 & 0.35 \\
Stress & 26.47 & 1 & 26.47 & 10.99 & 0.002 & 0.25 & 0.89 \\
\hline
\end{tabular}

According to the results of Table 3, The SIT had a significant impact on scores of depressions and stress in the participants $(\mathrm{F}=22.42, \mathrm{P}=0.0001)$ and stress $(\mathrm{F}=10.99, \mathrm{P}=0.002)$, but had no significant impact on their anxiety $(\mathrm{F}=0.19, \mathrm{P}=0.66)$. Eta square values showed that 41 and 25 percent of the variation in the depression and stress variables were due to the intervention impact, respectively.

\section{Conclusion}

The SIT improved adaptive strategies of cognitive emotion regulation and psychological problems of depression and stress in mothers of blind children. These findings are consistent with the findings of Kang et al. (28), Ashori et al. (25), and Sheehy and Horan (22) on the significant effect of SIT. To an explanation of these findings, it can be concluded that the SIT has an impact on subjective well-being and individual's emotional experiences; that it influences on their psychological reactions (25). 
Therefore, this program important role play on cognitive emotion regulation and psychological problems of the mothers of blind children.

Another finding of this study indicated that the SIT had no significant effect on maladaptive strategies of cognitive emotion regulation and anxiety of subjects, which is inconsistent with the results of Kang et al. (28) and Jenaabadi (26). To explain this finding, it can be said that the lower the adaptation of blind children, the more extreme the behaviors in response to anxiogenic situations (4). Therefore, increase the maladaptive behaviors and anxiety in their mothers. In addition, sometimes mothers of blind children have different and unique problems, and it seems that because the SIT program was implemented as a group, it did not have a significant effect on their maladaptive strategies of cognitive emotion regulation and anxiety.

The most important strength of the present study was the simultaneous focus on cognitive emotion regulation and psychological problems of the mothers of blind children. Since a quasi-experimental method was conducted in the present study, the results should be generalized with caution. Another limitation of this resear ' ch was the use of the SIT for mothers of blind children in a group method. It is recommended that this program be used individually for parents of blind children.

\section{Ethical Considerations}

Compliance with ethical guidelines: The issuing permit of conducting the present study was emitted by the The Organization of Exceptional Children Education in Isfahan on 2018/12/23. Also in this research, other ethical considerations such as informed consent of the sample and observing the principle of confidentiality and confidentiality of information have been observed.

Funding: This research was conducted without any sponsor and in the form of a master's thesis.

Authors' contribution: This research is extracted from the master's thesis of Mr. Ehsan Bahramfar in psychology and education of people with special needs in the University of Isfahan with the code 68594/97 and dated 2018/11/26. The first author conducts the research, and the second author was the research supervisor.

Conflict of interest: The results were reported without any bias, and the authors declare there is no conflict of interest in the present findings.

Acknowledgments: We would like to thank all the officials of the The Organization of Exceptional Children Education in Isfahan, especially the research expert, who coordinated with the school for the implementation of education and research, as well as the administrative staff, teachers, and the participants who helped us in the implementation of this study. 


\section{اثر آموزش ايمن سازى روانى در برابر تنيدىى بر تنظيم شناختى هيجان و مشكلات روانشناختى مادران كود كان نابينا}

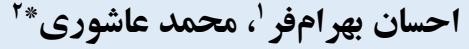

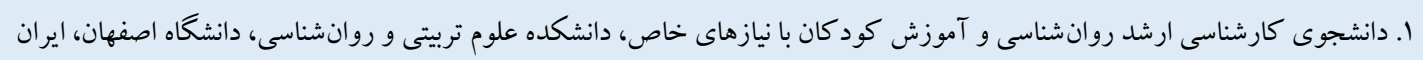

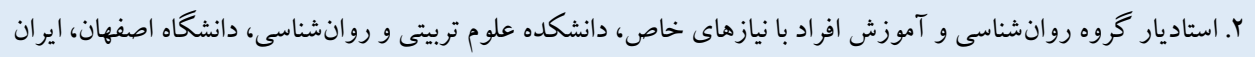

\section{جك:}

زمينه و هدف: مادران كودكان نابينا در تنظيم هيجان و واكنشهاى روانشناختى با مشكل مواجه هستند. به نظر مىرسد كه آموزش

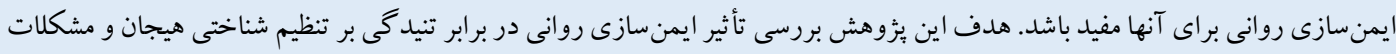
روانشناختى مادران كود كان نابينا بود.

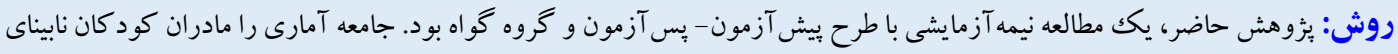

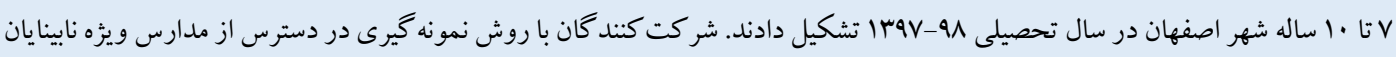

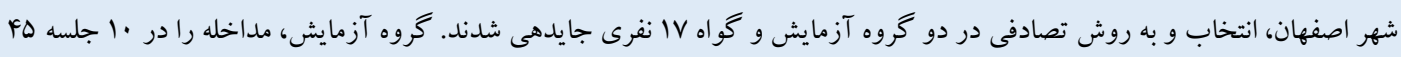

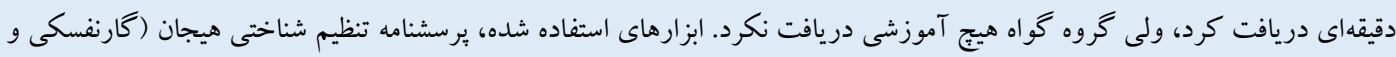

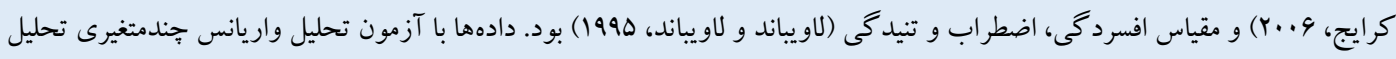

شد.

يافتهها: نتايج نشان داد كه آموزش ايمنسازى روانى اثر معنادارى بر نمرههاى افتراقى راهبردهاى سازشيافته تنظيم شناختى هيجان در

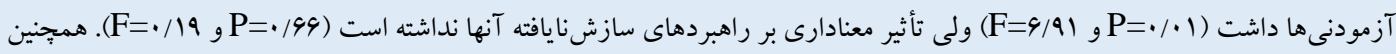

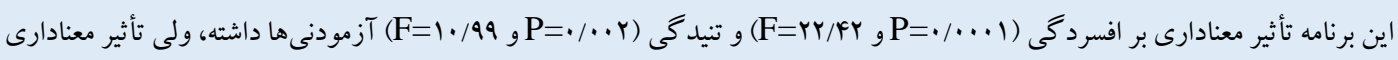

$$
\text { بر اضطراب آنها نداشت (F=. P }
$$

نتيجه كيرى: برنامه ايمنسازى روانى بر تجربههاى هيجانى و واكنشهاى روانشناختى تأثير مى گذارد؛ بنابر اين، نقش مهمى در بهبود تنظيم هيجان و مشكلات روانشناختى مادران كود كان نابينا دارد.
مشخصات مقاله

كليدوازهها: ايمنسازى روانى در برابر تنيدگى، تينى تنظيم شناختى هيجان، كود كان نابينا

* نويسنده مسئول: محمد عاشورى، استاديار گروه روانشناسى و آموزش افر اد با نيازهاى خاص، دانشكده علوم تربيتى و روانشناسى، دانشگاه اصفهان، ايران. M.ashori@edu.ui.ac.ir رايانامه: 
احسـاسـات بدنى مربوط به هيجان، درك برانگيختخى هيجانى، تعديل

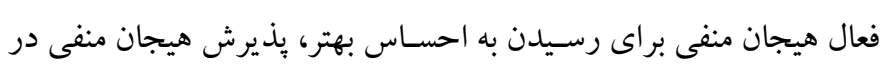
زمان لزوم و تحمل آن از مهارت هاى تنظيم هيجان هستند (11).

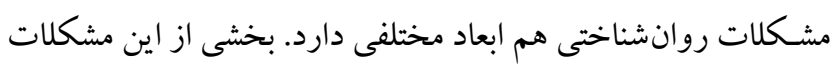

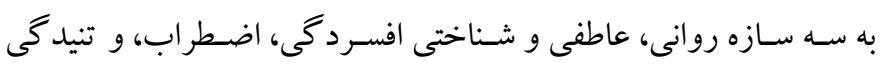

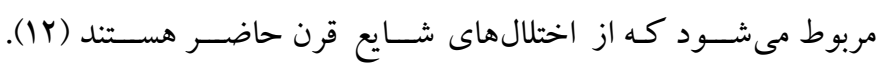

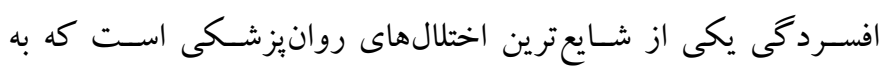

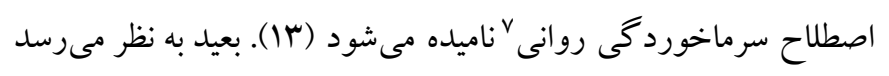

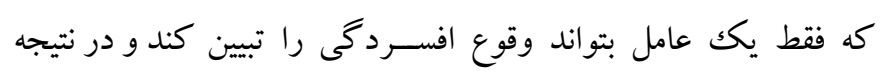

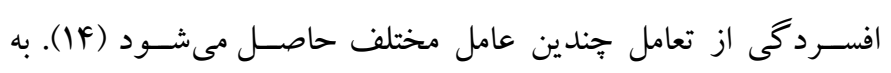

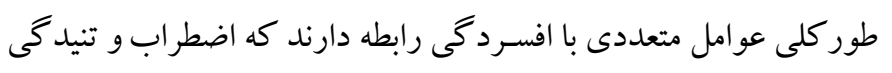

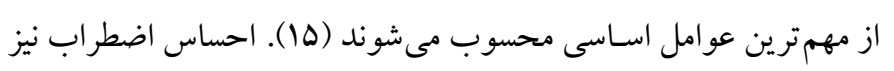

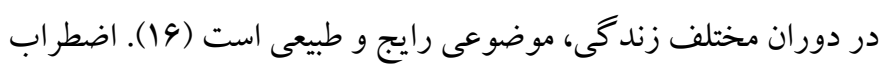

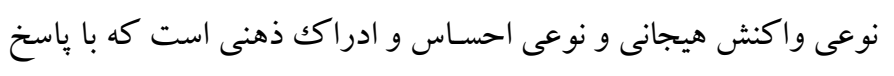

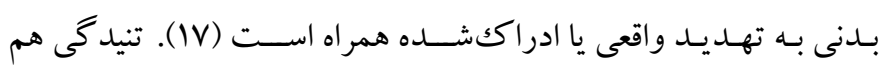

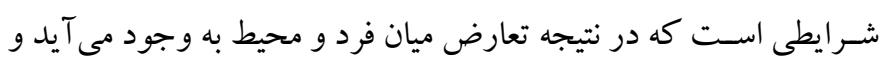

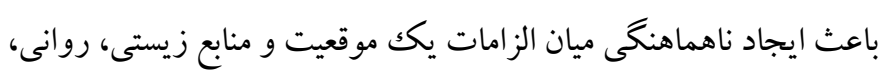

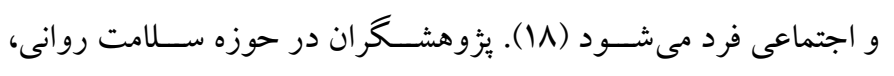

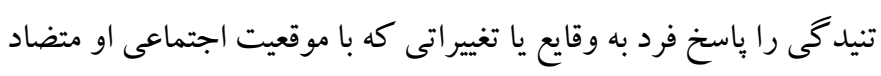

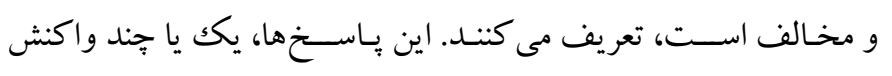

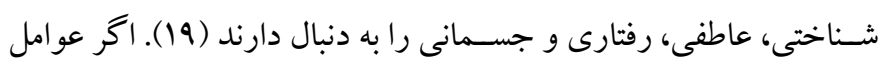

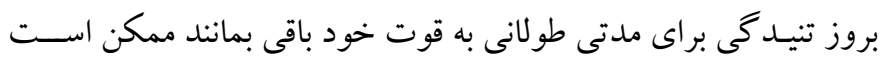

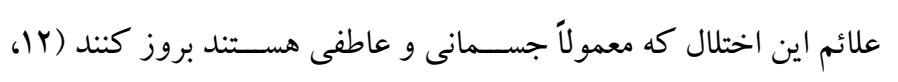

. $(Y$.

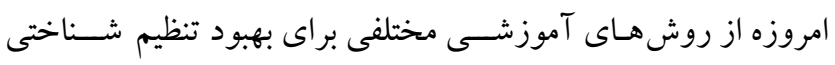

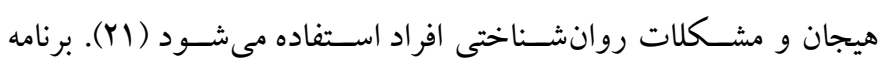

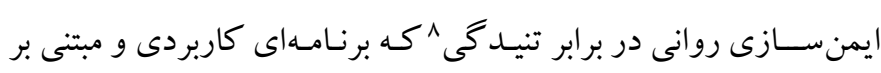

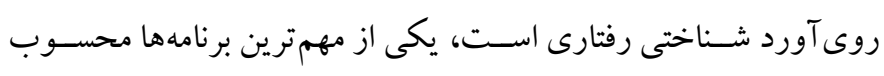

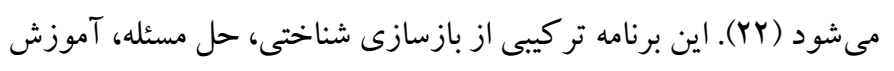

\section{Stress}

6. Emotions

7. Mental cold

8. Stress inoculation program
مقلهمه

افر اد با آسـيب بينايى' بخشــى از افراد جامعه هســند اما كاهى كمى يا

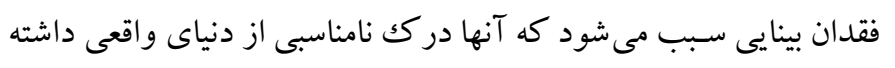

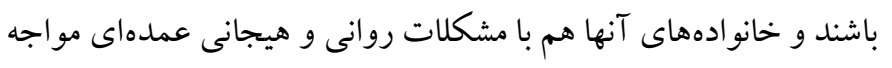

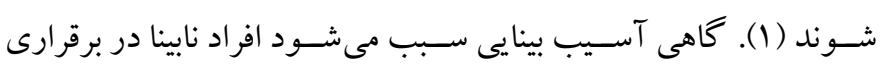

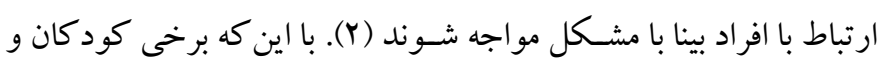

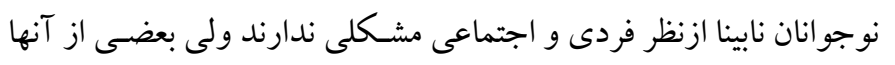

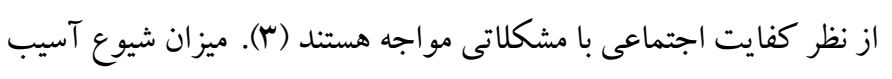

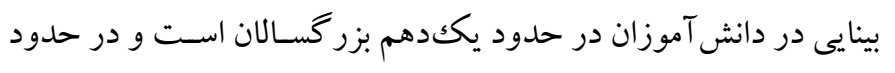

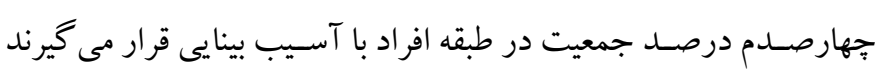

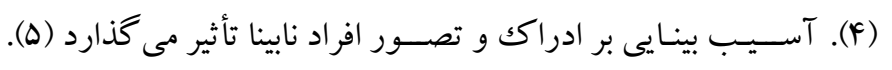

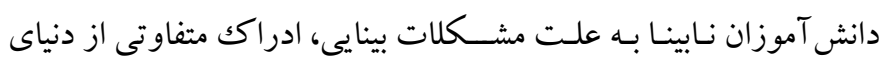

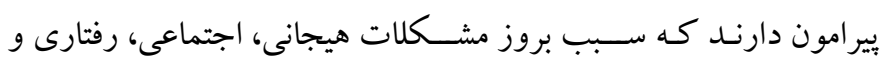
روانشـــاختى در آنها و حتى خـانوادههايشــان، بهويزه در مادران آنها

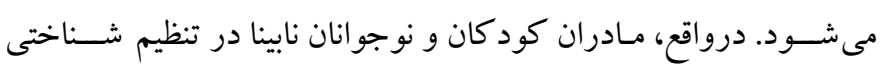

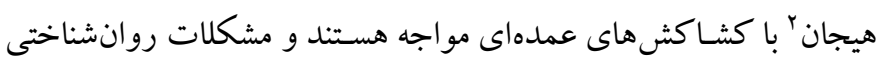

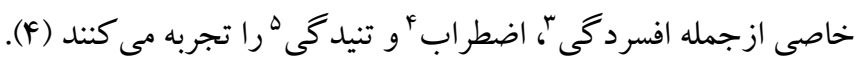

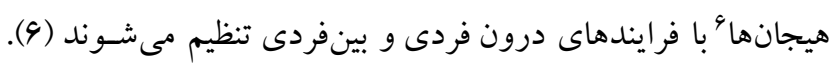

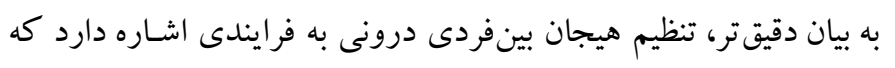

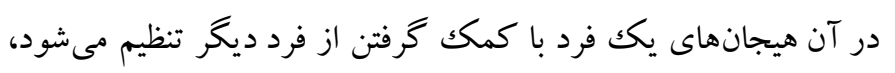

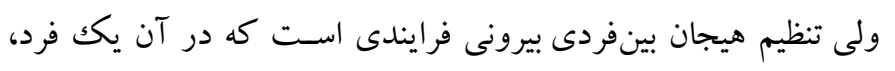

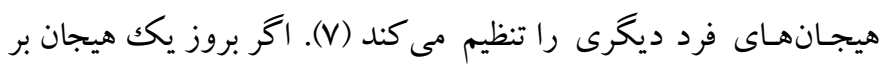

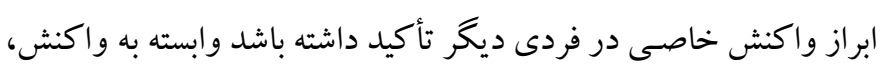

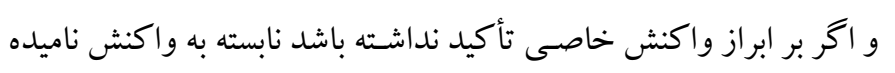

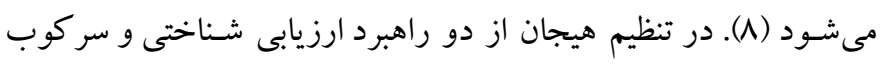

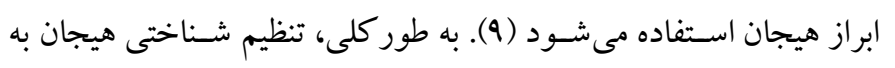

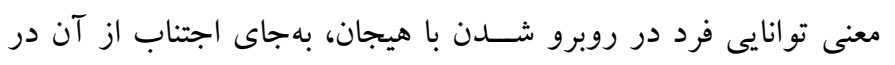

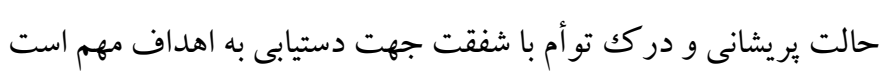

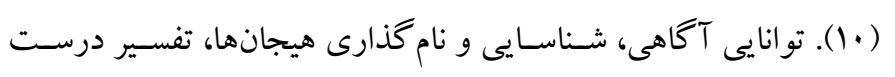

1. Individuals with visual impairment

2. Cognitive emotion regulation

3. Depression

4. Anxiety 
مخالف افكار خود آيند دست يابد، موقعيت ايجاد كننده تنش را بررسىى كنـد و بتواند تعارض هاى خود را كاهش داده يا برطرف كند. به اين معنا كه به نظر مىرسـد حل مسـئله شـناختى، هدف گزينى مطلوب و انتخاب راهبردى كار آمد كه با برنامه ايمنسـازى روانى آموزش داده مى شود در بهبود روابط و عملكرد مادران كود كان نابينا و افزايش رفتارهاى مطلوب آنها مؤثر واقع شــود كـه اين موارد بيانكر اهميت و ضـــرورت بزوهش حاضـر هسـتند. از ســوى ديخر، مادران كود كان نابينا نسـبت به مادران كود كـان بينا از نظر تنظيم هيجانهاى خود با مشـكلات بيشــترى مواجه

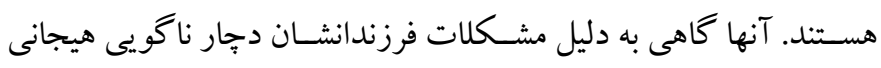
مىشـوند و اين موضـوع نيز مشـكلات روانشناختى آنها را بيشتر مى كند.

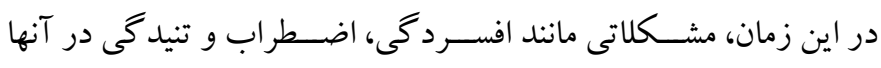
آشــكـارتر مى شــود و تأثير منفى و نامطلوبى بر زندگى آنها مى گذارد. علاوه بر اين، دور از انتظار نيست كه آموزش مهارت ايمنسازى روانى به مـادران كودكـان نـابينـا، توان و جرئست مقابله با مشــكلات را بدهد. اين توانمندى موجب مى شــود تا آنها تنظيم شــناختى هيجان مطلوبـترى را

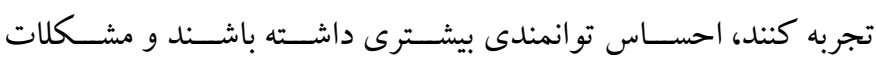
روانشـناختى شـان كمتر شـود؛؛ بنابر اين هدف اصـلى بزّوهش حاضـر، بررسـى اثربخشسى آموزش برنامه ايمنسـازى در برابر تنيدكى بر تنظيم شناختى هيجان و مشكلات روانشناختى مادران كود كان نابينا بود.

روش

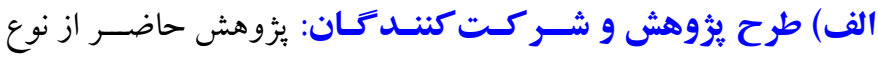

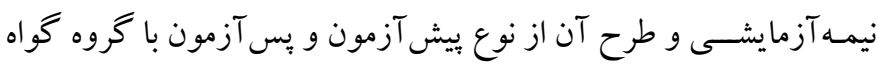

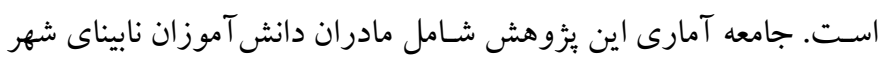

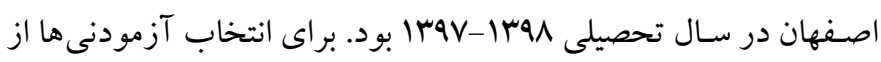

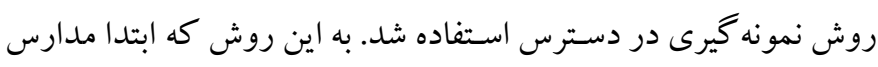

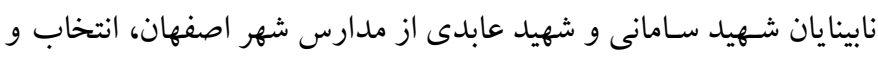

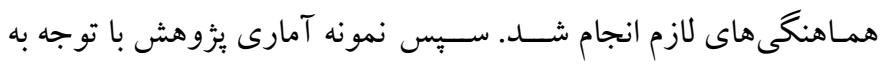

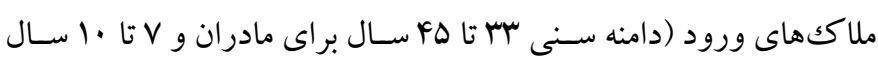

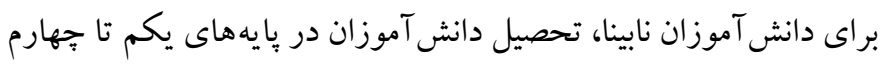

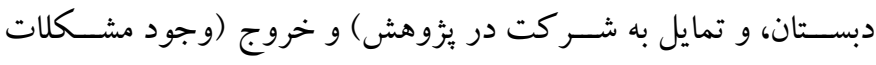
نـاشـــوايى و كم توانى ذهنى در دانش آموزان، طلـاق يـا جـدايى مادر از
تنشزدايى، تمرين مجسمسـازى ذهنى و رفتارى، خود آموزى، و تقويت

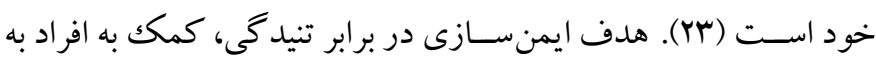
منظور كسترش و كسـب مهارتهاى مقابلهاى براى مشـكلات كنونى و

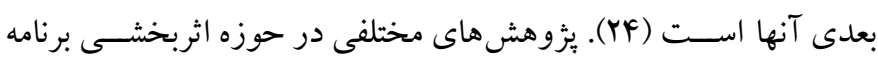

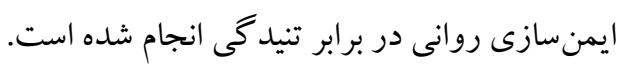
يافتهاى بززوهش عاشــورى، نخســين و قزاقى (YD) حاكى از تأثير

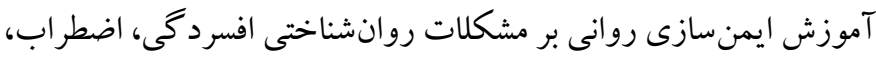

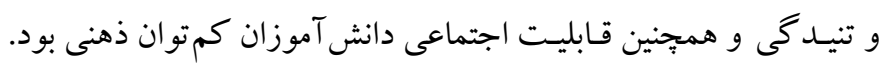

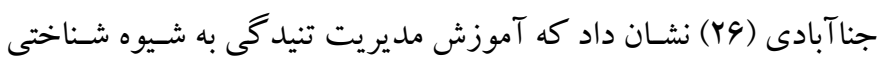

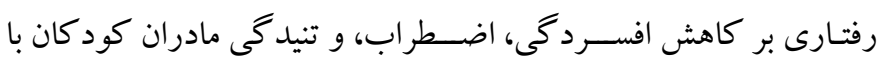

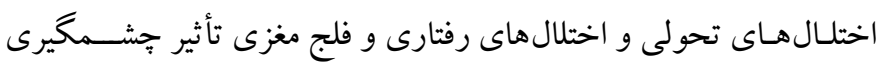

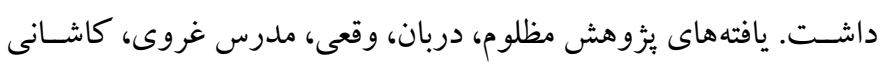

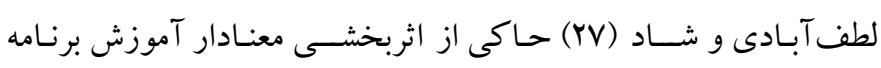
ايمنســازى بر ســلـامـت عمومى و خردمدقـاس هـاى آن ازجمله علائم

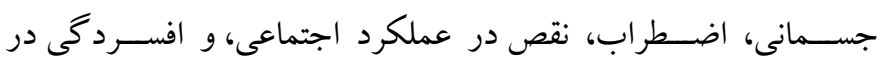

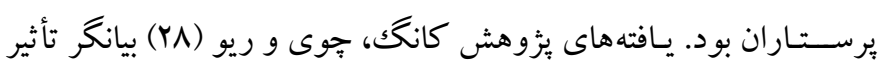

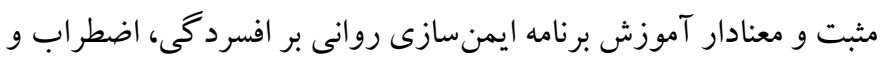

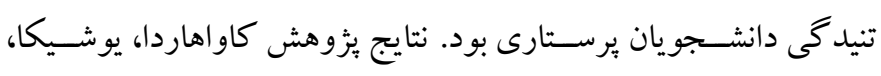

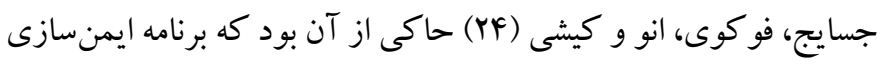

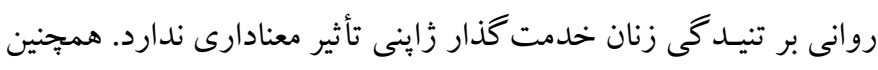

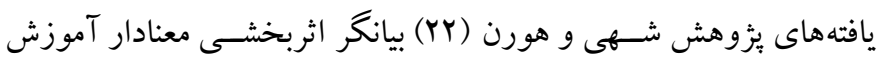
برنامه ايمنسـازى بر تنيدگى، اضطراب و مشكلات هيجانى دانشجويان

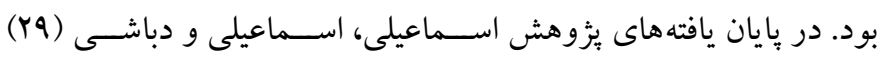

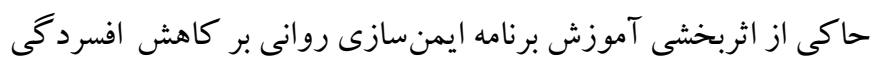

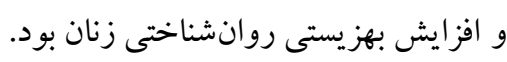

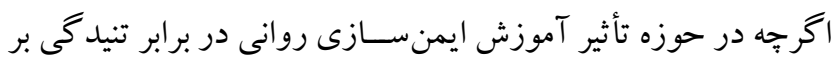

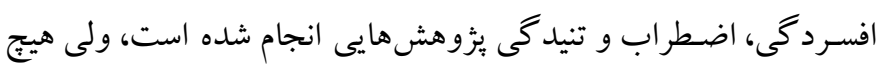

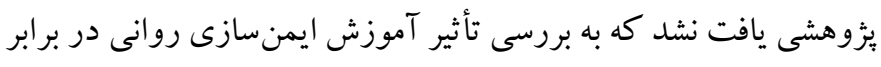

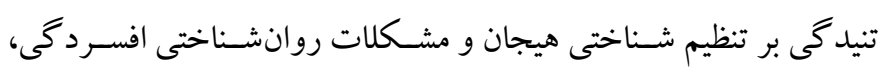

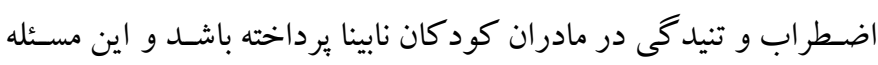

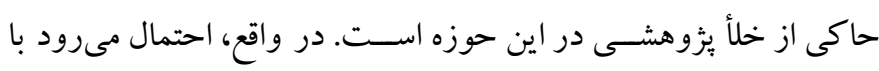

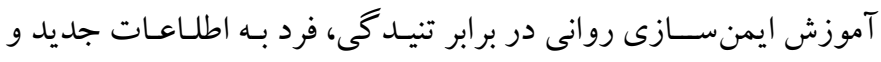


كرونباخ راهبردهاى سـازشنايافته و سـازش يافته به ترتيب NV · و • • •

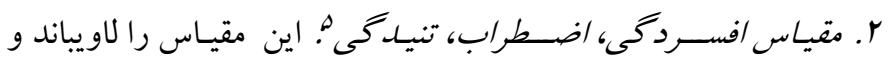

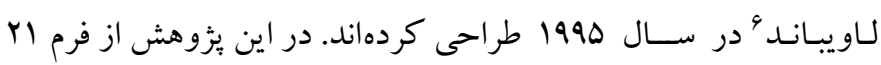

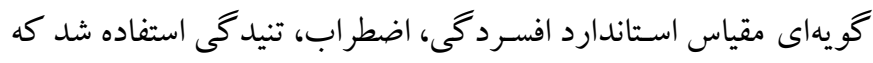

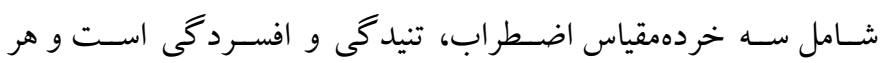

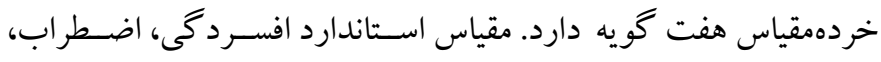
تنيدگى به روش ليكرت نمره گذارى مىشسود و داراى گزينه هاى اصسلاً

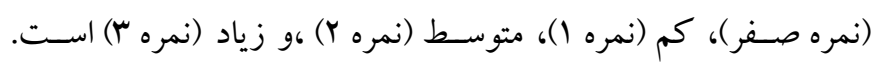

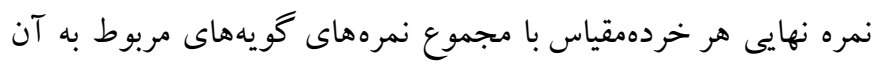

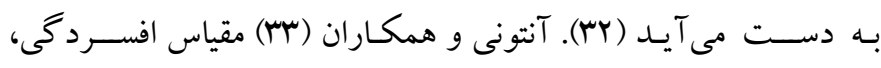

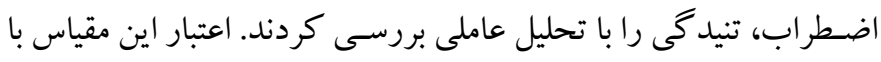

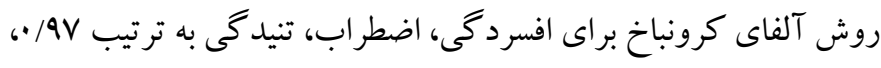

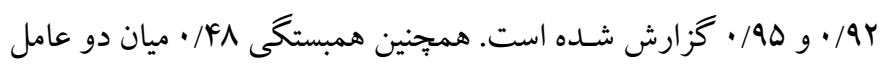

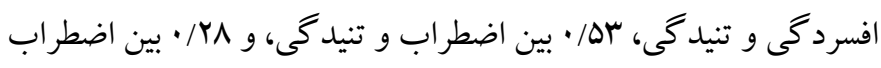
و افسـرد گى به دسـت آوردند. ســامانى و جو كار (FF) روايى و اعتبار

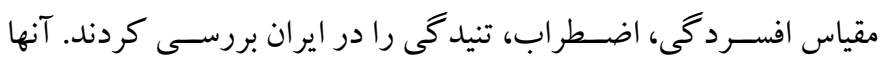

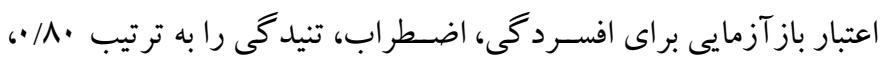

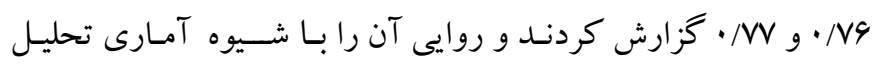
عاملى از نوع تأييدى و به روش مؤلفههاى اصلى •ج/· به دست آوردند.

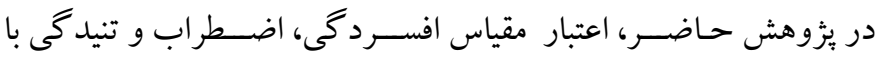

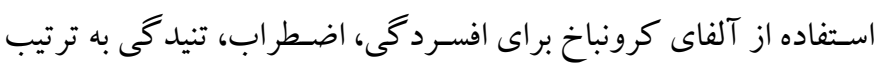

$$
\text { •/9/9 • • • و 199، • به دست آمد. }
$$

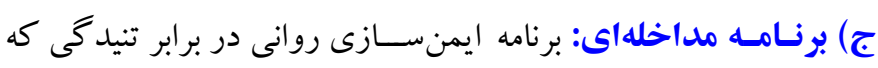

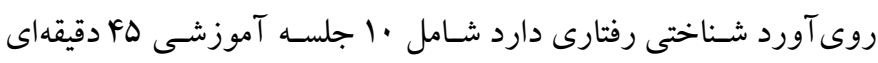

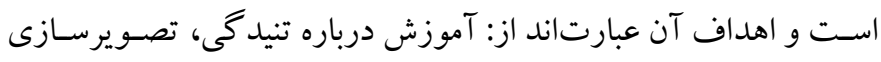
ذهنى مثبـت، آرامشدهى و تنش زدايى، بـازســازى شـــــاختى، افكار

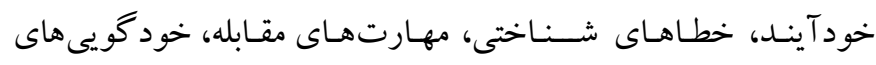
هدايتشده، تمر كز، مديريت زمان، حل مسئله اجتماعى، خودنظمبخشى، مهنى

\section{Adaptive strategies}

5. Depression anxiety stress scales

6. Lawibund \& Lawibund
همسـر و فرزندان، اسـتفاده از برنامههاى روانشــناختى همزمان بامطالعه حاضـر ) مشـخص شـــند. به منظور تعيين حداقل حجم نمونه و با در نظر

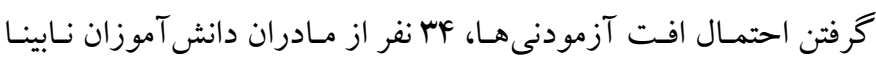

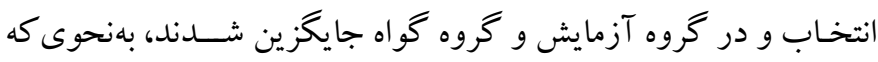
اعضاى هر گروه ا نفر بود.

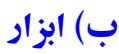

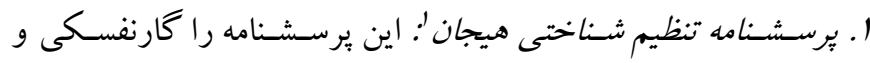

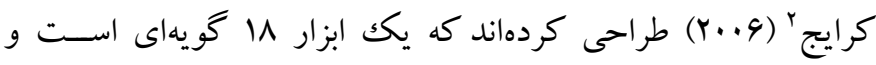

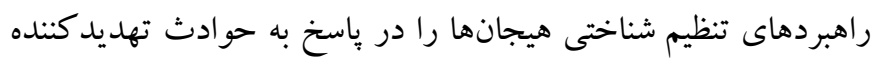

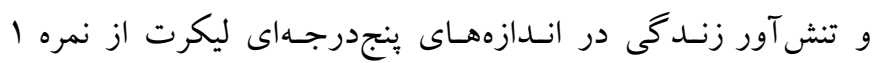

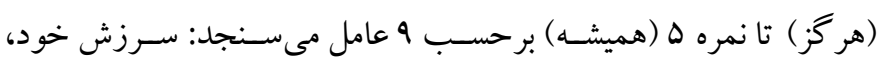

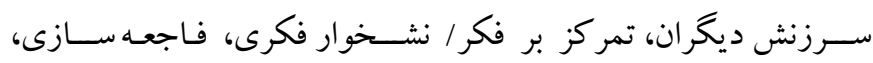
كماهميتشـمارى، تمر كز مجدد مثبت، ارزيابى مجدد مثبت، بذيرش،

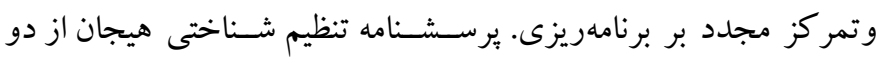

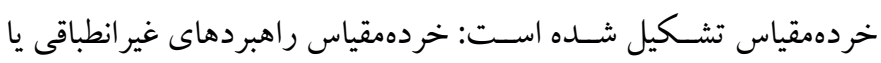
سـازش نايافته باز جهار عامل نخست، و همجينين خردهمقياس راهبردهاى

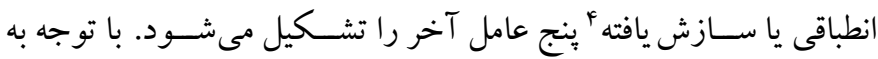

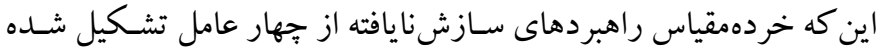

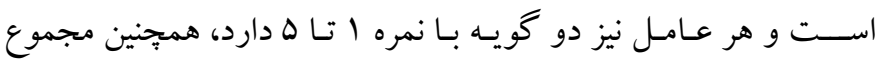

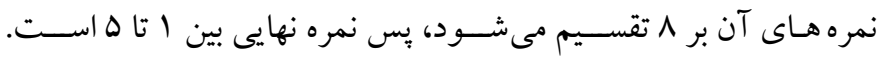

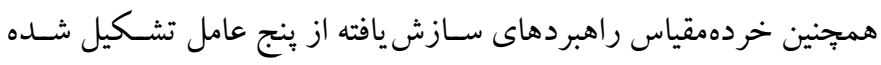

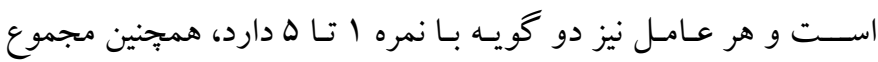

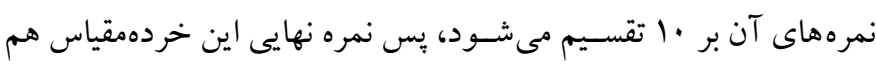

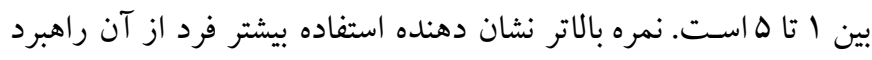
شـناختى محسوب مى شود. اعتبار اين برسشنامه به روش آلفاى كرونباخ

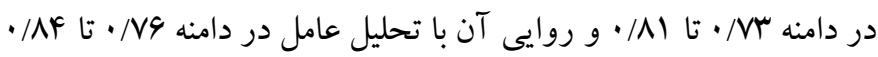

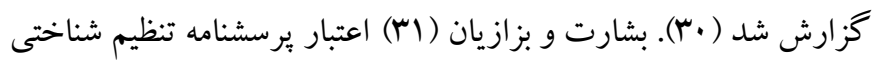

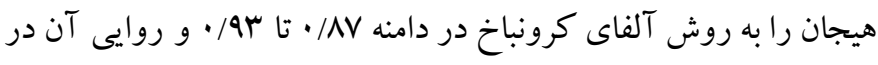

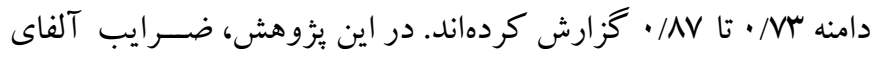

1. Cognitive emotion regulation questionnaire

2. Garnefski \& Kraaij

3. Maladaptive strategies 
و خود كار آمدى. اين برنامه (جدول () توسط عاشورى و همكاران (Y) (Y)

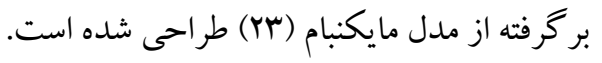

جدول 1: محتواى جلسات آموزش برنامه ايمنسازى روانى در برابر تنيدكى

\begin{tabular}{|c|c|c|c|}
\hline تكليف & محتوا & هدف & جلسه \\
\hline ثبت تجربيات واقعى زندگى روزمره & 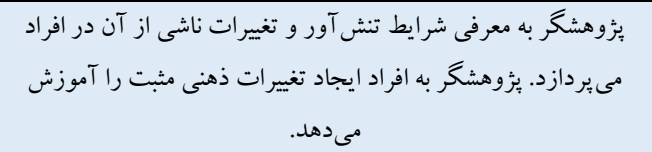 & 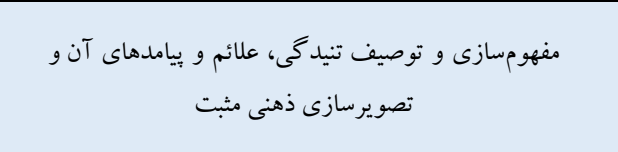 & 1 \\
\hline تمرين تنشزدايى و آرامشدهى & يززوهشكر الخوهاى آرامشدهى در شرايط تنش آور را ارائه مىدهد. & آموزش آرامشدهى و تنشزدايى & r \\
\hline 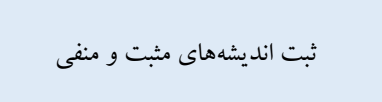 & هُزوهشخ افراد را به سمت شناسايى افكار و احساسات مؤثر در شرايط & 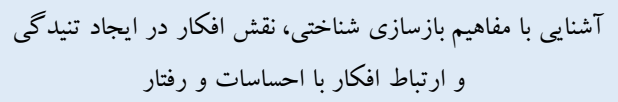 & $r$ \\
\hline كاربر گك ثبت خطاهاى شناختى آكاهانه & 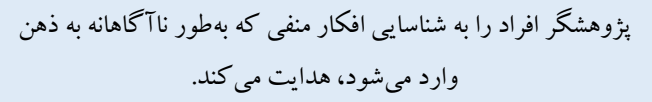 & آشنايى با ويز گىهاى افكار خود آيند منفى و خطاهاى شناختى & F \\
\hline ثبت راهحل هاى مقابله با افكار نامناسب & آموزش مهارتهاى مقابله با تنيدگى و جِكونخى مقابله با افكار منفى & مهارت ماى مقابله & $\Delta$ \\
\hline تمرين خودگويى آكاهانه ارزشها & آموزش خود گويى هاى هدايتشده و نقش خود گويىهاى منفى در & خود گو يى هاى هدايتشده & 9 \\
\hline كاربر كى ثبت نحوه تمركز و تغيير توجه & يُزوهشخر تكنيك هاى توجه بر گردانى و تمر كز فكر را آموزش & تمركز فكر و تكنيككهاى توجه بركردانى & v \\
\hline تمرين در حال زيستن و مديريت زمان & آموزش مديريت زمان در هنگام بروز تنيدگى و حل مسئله اجتماعى & مديريت زمان و حل مسئله اجتماعى & $\wedge$ \\
\hline كاربر گ ثبت وقايع هدفمند روزانه & 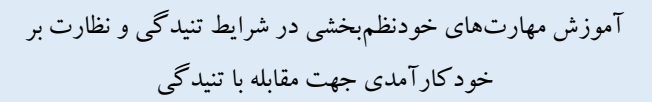 & مهارت هاى خودنظمبخش و نظارت بر خود كار آمدى & 9 \\
\hline كاربر كَ ثبت موانع و راهكارهاى عملى & 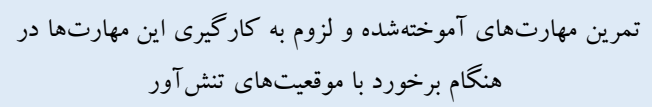 & تمرين مهارت ها & 1. \\
\hline
\end{tabular}

(نويسنده نخست بار اهنمايى و همكارى نويسنده دوم) به روش گروهى به آزمودنى ها آموزش دادند و براى آموزش از روشهاى سخنرانى، يرسش و ياســخ، ايفاى نقش و روش نمايشى، و همبحنين براى آموزش مفاهيم از فيلم و ياوريوينت اســتفاده شــــ. به منظور رعايت اخلاق در يزوهش، از والدين آزمودنى ها رضـايتنامه كتبى كرفته شــد و به آنها اطمينان داده شـــ كه اطلاعات اسـتخر اج شـده و نام آزمودنى ها بهطور محر مانه باشـــ، بـهنظور حفظ اســرار شــخصـى و عدم تجاوز به حريم خصــوصسى شـركت كنند كان نتايج حاصـل از يثزوهش در سطح كلى كزارش شود تا براى بيشـبرد اهداف بزووهش در اختيار روانشـناسـان و متخصـصـان قرار

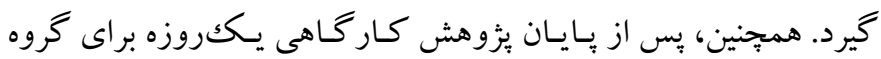
كواه كذاشـته شـد و يكك جزوه آموزشـى درباره برنامه مداخلاتى به آنها داده شـد. در پايان جلسات آموزش، آزمودنىهاى هر دو گرووه پيرسشنامه تنظيم شـناختى هيجان و مقياس افسـردگى، اضسطر اب، تنيدگى را تكميل
د) روش اجرا: براى انجـام يثوهش از مديريت آموزشويرورش شــهر اصسـفهـان، معرفى نامه دريافت شـــد و با ملديريت محترم مدارس نابينايان

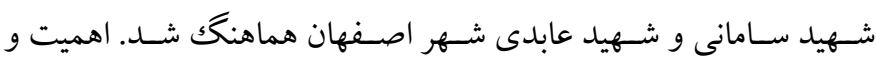
ضـرورت بزٔوهش حاضـر براى مديران و مشاوران مدارس مورد نظر بيان شــــ. بعـد از انتخـاب آزمودنىهـا بر اســاس ملـاككهاى ورود و خروج يثوهش و جـايـدهى آنها در گروه آزمـايش و كواه، ابتدا به آزمودنىها درباره نحوه تكميل برسشنامهها توضيح داده شد. آنها در نخستين مرحله يثوهش، يرسشنامه تنظيم شناختى هيجان و مقياس افسردگى، اضطراب،

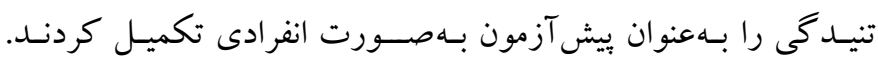

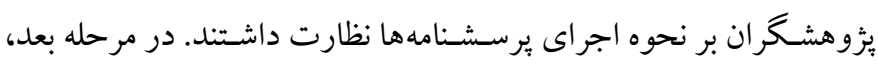
كروه آزمايش در · ا جلسـه آموزشسى ها دقيقهاى (هفتهاى Y جلسه) كه در مدرسـه نابينايان شهيد سامانى اصفهان بر گزار شد شركت كردند، ولى بر ای گروه گواه هيج آموزشى ارائه نشد. محتواى جلسات را بثزوهشخران 


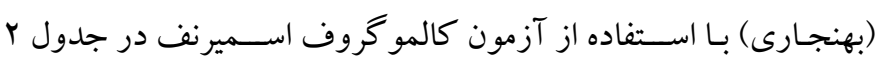

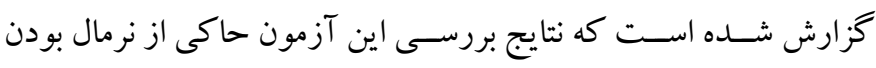

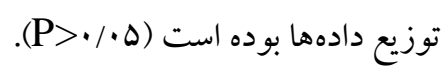

شــاخص هاى توصسيفى مربوط به تنظيم شــناختى هيجان (راهبردهاى

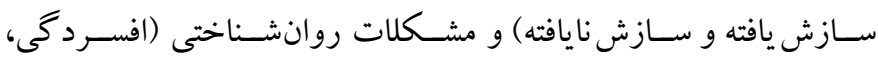

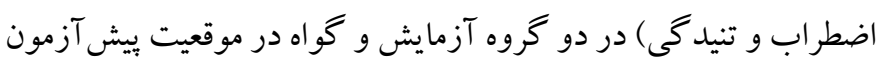
و بِس آزمون در جدول ب ارائه شده است.
كردند و نمره هاى آنها بهعنوان بِ آزمون در نظر كرفته شـــ. دادههاى

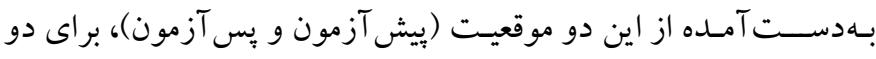

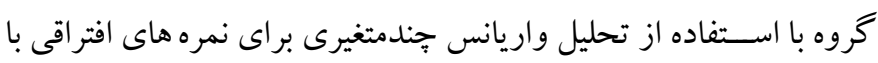
نسخه سب نرمافزار آمارى SPSS تحليل شدند.

يافتهها ميانگين و انحر اف استاندارد نمرههاى ييش آزمون و پِ يس آزمون متغيرهاى

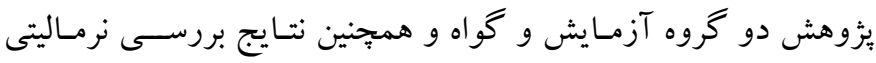

جدول r: شاخصهاى توصيفى تنظيم شناختى هيجان و مشكلات روانشناختى

\begin{tabular}{|c|c|c|c|c|c|c|c|c|}
\hline \multicolumn{3}{|c|}{ كروه كواه } & \multicolumn{3}{|c|}{ كروه آزمايش } & \multirow{2}{*}{ موقعيت } & & \multirow{2}{*}{ متغيرها } \\
\hline بهنجارى & انحراف معيار & ميانكين & بهنجارى & انحراف معيار & ميانكين & & & \\
\hline$\cdot / r$. & $1 / 4 r$ & T/AY &.$/ 1$ & $1 / 41$ & $r / \Delta \Lambda$ & يِيش آزمون & \multirow{2}{*}{ سازش يافته } & \multirow{4}{*}{ راهبردهاى تنظيم هيجان } \\
\hline.$/ 10$ & $1 / 4 \Lambda$ & $r / V F$ & .1 .4 & $|/ 4|$ & $r / \Delta r$ & يִ آزمون & & \\
\hline.$/ .9$ & $1 / 1 r$ & $r / \Delta r$ & $\cdot / / f$ & $1 / .9$ & $r / \Delta \Lambda$ & يِيش آزمون & \multirow{2}{*}{ سازشنايافته } & \\
\hline .1 .9 & $1 / 1 r$ & $r / q V$ & .1 .4 & $1 / \Delta F$ & $r / \Delta \Lambda$ & يس آزمون & & \\
\hline$\cdot / \cdot v$ & . /9r & $M / M$ &.$/$ & $1 / 11$ & MNGF & يِيش آزمون & \multirow{2}{*}{ افسردگى } & \multirow{6}{*}{ مشكلات روانشناختى } \\
\hline.$/ f F$ & $1 / .9$ & $\mid N / \Delta \Lambda$ & $\cdot / 11$ & $1 / Y F$ & $10 / 9 F$ & يس آزمون & & \\
\hline$\cdot / l F$ & $1 / .9$ & $|f / f|$ &.$/ 11$ & I/r & $\mid F / F V$ & ي يش آزمون & \multirow{2}{*}{ اضطراب } & \\
\hline$\cdot / \mathrm{V}$ & $1 / 91$ & $\mid q / r \Delta$ & $\cdot / r$. & $1 / \Delta r$ & $\mid r / r q$ & يس آزمون & & \\
\hline$\cdot 1$ & $1 / F V$ & $19 / 94$ &.$/$ & $1 / 4 \pi$ & $\mathrm{IV} / \cdot \Delta$ & ي بيش آزمون & \multirow{2}{*}{ تيدگى } & \\
\hline.$/$ If & $1 / 44$ & $|V / I|$ &.$/ 19$ & $1 / 19$ & $\mid F / r q$ & پِ آزمون & & \\
\hline
\end{tabular}

واقع، به علت وجود يكك متغير مسـتقل (آموزش ايمنســازى روانى در

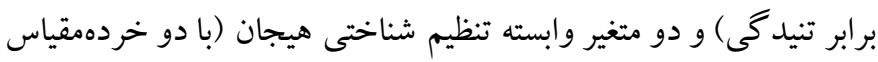

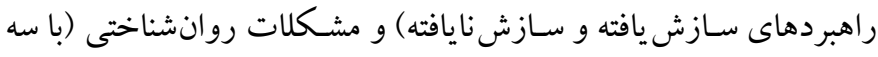
خردهمقياس افسردگىى، اضطر اب و تنيدگى) از دو آزمون آمارى تحليل

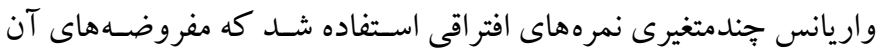
برقرار است و مىتوان جهت تحليل دادهها از اين آزمون استفاده كرد.

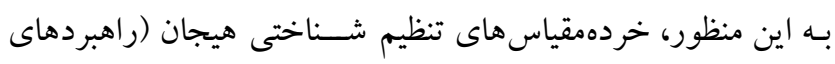

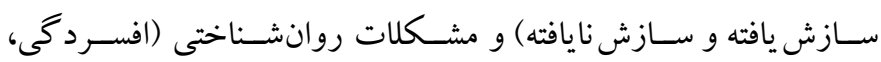

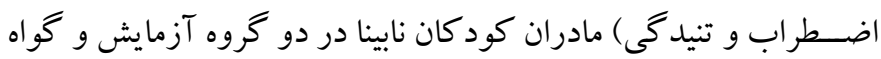
در ويشفرض آمـارى لـامبـداى ويلكز محاسـبه شــــ كه در تحليل اول

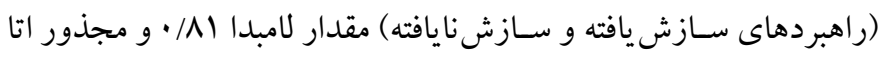

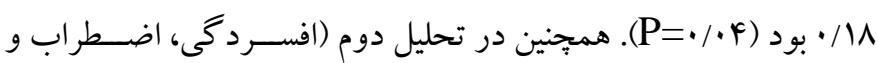

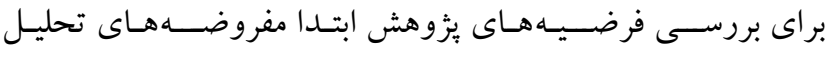

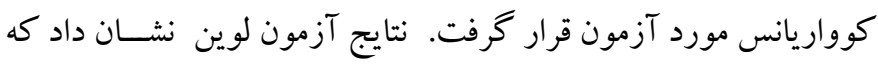

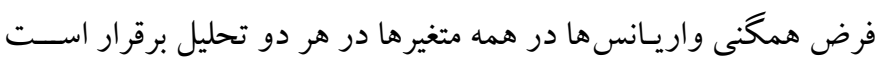

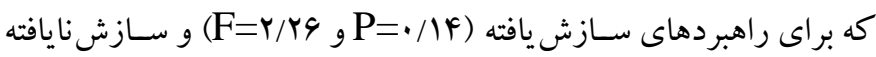

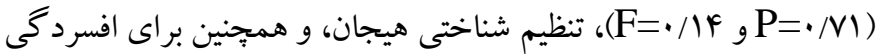

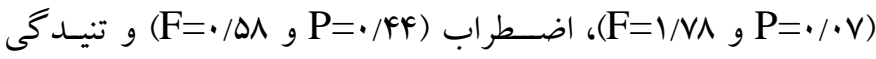
(F=1/.9 , بود. آزمون بـاكس فرض همخنى واريـانس

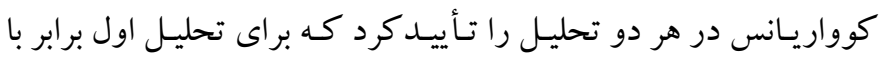

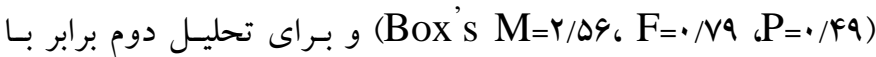

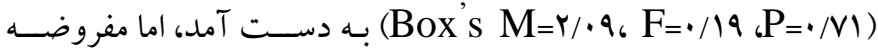

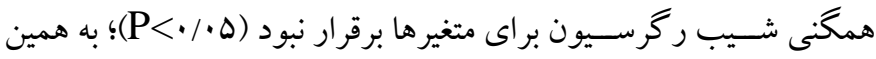

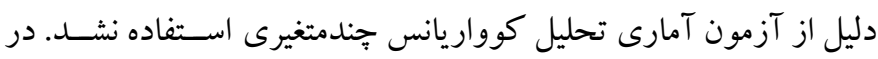


و تنيـدگى) تفـاوت معنـادارى دارنـد. بـهم نظور بـى بردن بـه تفـاوت در

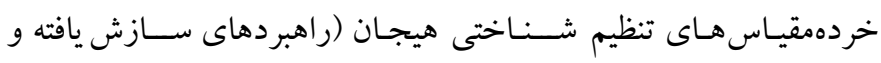

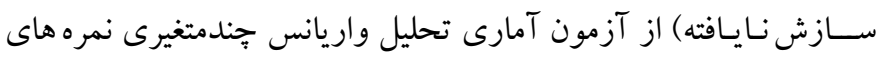

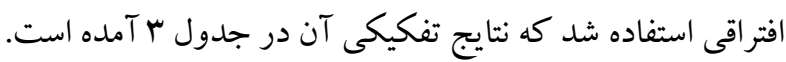

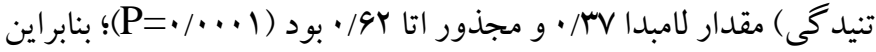

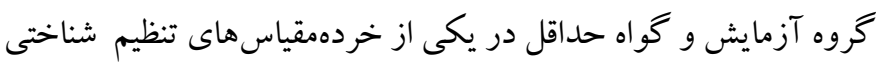

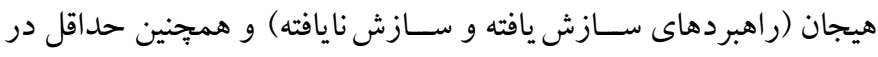

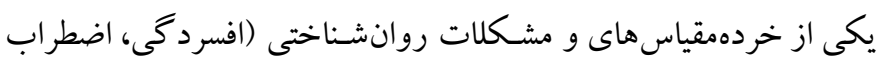

جدول با: نتايج تفكيكى تحليل واريانس جندمتغيرى نمرههاى افتراقى براى خردهمقياسهاى تنظيم شناختى هيجان

\begin{tabular}{|c|c|c|c|c|c|c|c|c|}
\hline ت توان ازمون & مجذور اتا & سطح معنادارى & F آماره F & ميانكين مجذورات & درجه آزادى & مجموع مجذورات & \multicolumn{2}{|c|}{ متغير هاى وابسته } \\
\hline$\cdot / \mathrm{Vr}$ &.$/ 1 V$ & $.1 \cdot 1$ & $9 / 91$ & $r / \Delta \Delta$ & 1 & $r / \Delta \Delta$ & سازش يافته & 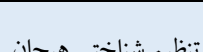 \\
\hline$\cdot / \cdot v$ & .1 .9 & .199 & $\cdot / 19$ & $\cdot / 11$ & 1 &.$/ 11$ & سازشنايافته & يجبل \\
\hline
\end{tabular}

اثر مـداخلـه اســت. براى تعيين تفـاوت در خردممقيـاس هاى مشـككلات

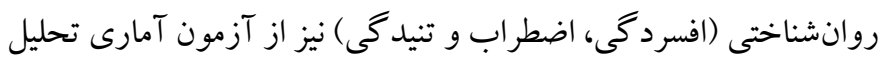

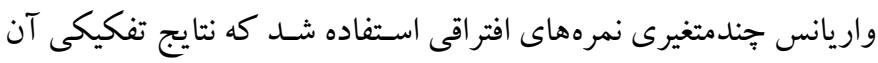
در جدول F ارائه شده است.

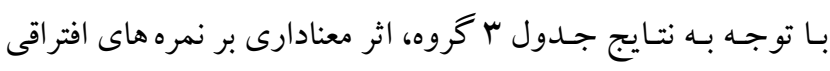

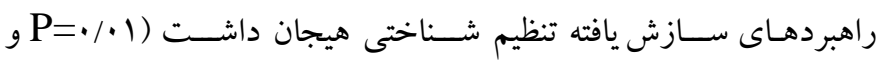

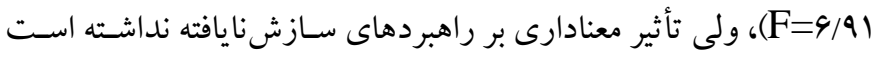

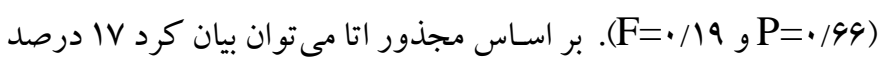
تغيير ات در متغير راهبردهاى سـازش يافته تنظيم شــناختى هيجان به علت

\begin{tabular}{|c|c|c|c|c|c|c|c|}
\hline توان آزمون & مجذور اتا & سطح معنادارى & F Toر & ميانكين مجذورات & درجه آزادى & مجموع مجذورات & متغير هاى وابسته \\
\hline.$/ 99$ & $\cdot|F|$ & $.1 \cdots 1$ & YY/FY & $r 9 / \cdot r$ & 1 & $r q / \cdot r$ & افسردگ \\
\hline 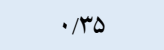 & $\cdot / \cdot V$ &.$/ 1$ & $Y / V I$ & $F / 9 V$ & 1 & $F / 9 V$ & مشكلات روانشناختى \\
\hline$\cdot / 19$ & $\cdot / \mathrm{T \Delta}$ & $\cdot / \cdot r$ & $1 . / 99$ & $r G / F V$ & 1 & $r G / F V$ & تنيدگى \\
\hline
\end{tabular}

شـناختى هيجان و مشكلات روانشناختى افسردگى و تنيدگى آزمودنىها تأثير معنادارى داشـت، ولى بر راهبردهاى سـازش نايافته تنظيم شـناختى هيجان و اضطراب آنها تأثير كمى داشت كه ازنظر آمارى معنادار نبود.

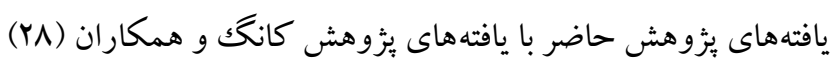
مبنى بر تأثير قابل توجه آموزش ايمنسازى روانى بر افسردگى و تنيدگى يُّى دانشـجويان؛ عاشـورى و همكاران (YD) درباره تأثير آموزش ايمنسـازى روانى بر كـاهش افسـردكى و تنيـدكى دانش آموزان كمتوان ذهنى؛ جنـآبـادى (Y9) مبنى بر اثربخشــى مثبـت آموزش مـديريت تنيدكى بر كاهش افسردگى و تنيدگى آزمودنى ها؛ شهى و هورن (YY) در راستاى اثربخشـى معنادار آموزش برنامه ايمنســازى بر تنيدكى و مشــكلات

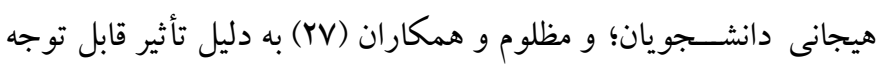
آموزش برنامه ايمنسـازى بر سـلامت عمومى، علائم جسـمانى، نارسـايى
بـا توجسه بـه نتـايج جـدول F، كروه اثر معنادارى بر نمره هاى افتراقى

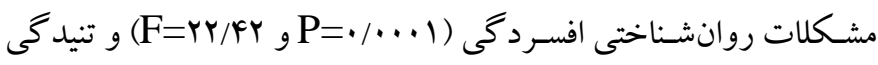

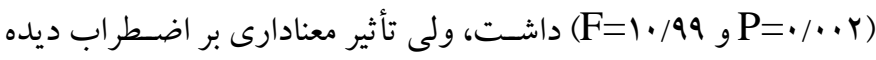

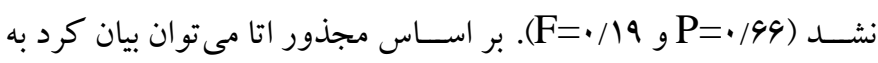

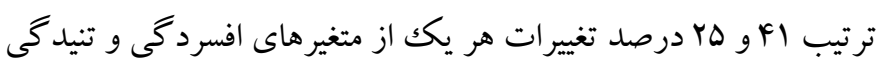
از شـركت مادران كود كان نابينا در برنامه آموزشى ايمنسازى روانى در برابر تنيدكى ناشى مىشود.

\section{بحث و نتيجه Fيرى}

هدف ئزوهش حاضسر، بررسى تأثير آموزش ايمنسـازى روانى در برابر تنيدكى بر تنظيم شــناختى هيجان و مشـكلات روانشـــاختى مادران كودكـان نـابينـا بود. نتـايج اين بثروهش نشـــان داد كـهـ آموزش برنـامـهـ ايمنســازى روانى در برابر تنيـدگى بر راهبردهاى ســازش يافته تنظيم 
ايمنسـازى روانى در برابر تنيدگى، بيشـتر بر راهبردهاى سـازش يافته و

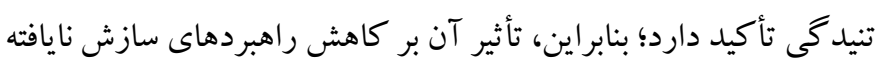
تنظيم شناختى هيجان آزمودنى ها معنادار نشد.

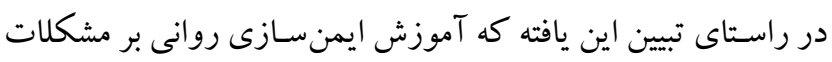

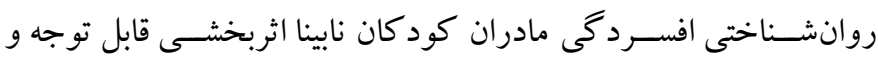

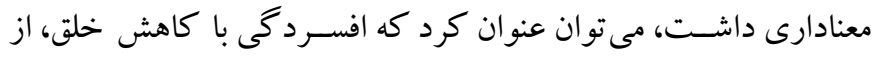

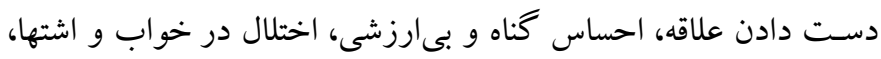

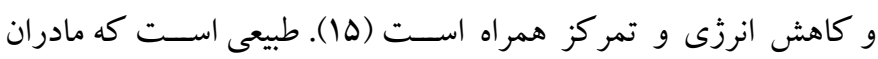

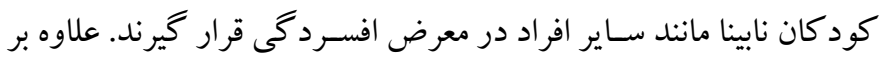
اين، شرايط زندكى و تحصيل فرزندان مى تواند اين وضعيت را بيجيجيده تر

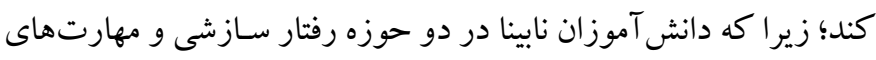

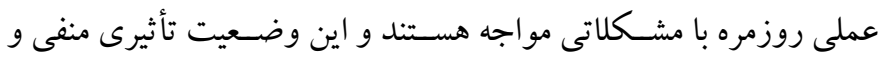

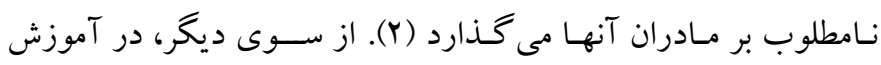

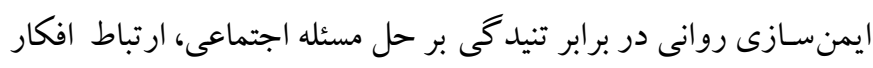

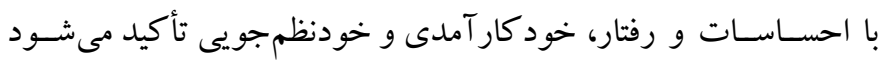
(Tr). به نظر مىرسـد آموزشى كه اين عوامل را يوشش دهد، بتواند توان

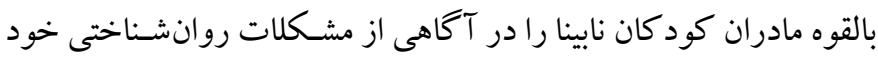

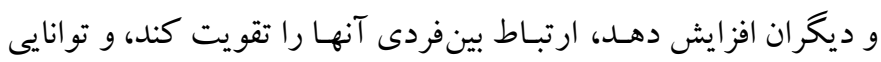

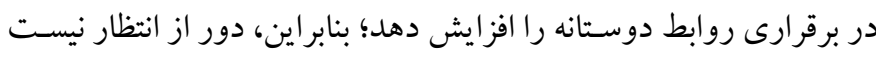

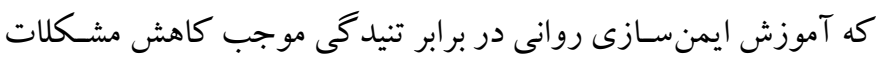
روانشناختى افسردگى در مادران كود كان نابينا شود.

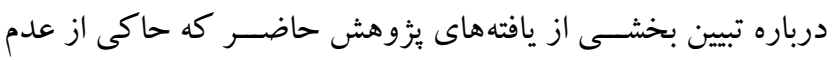

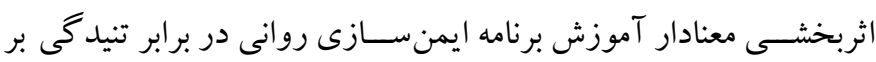

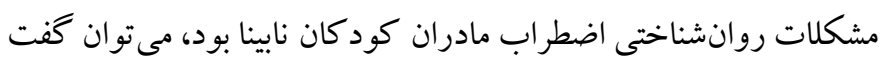

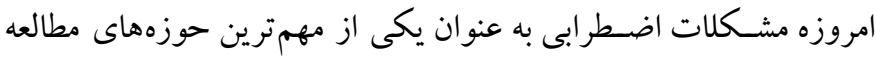
مشكلات روانشناختى نامطلوب انسان مطرح مى شود كه مادران كود كان

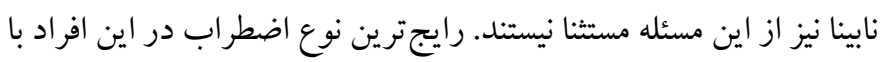

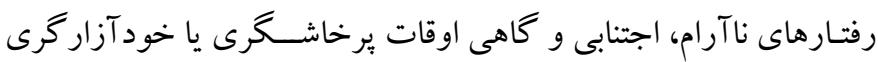

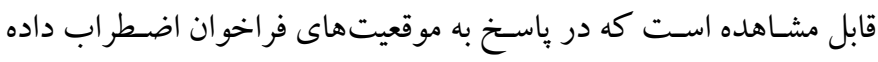

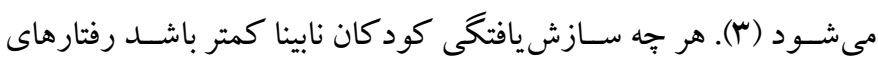
افر اطى ترى در هنگًام ياسخ به شرايط اضطر اب آور آزارنده محيطى نشان

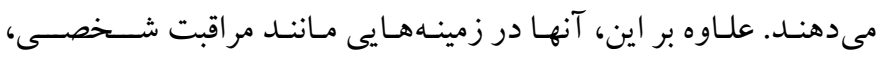

در عملكرد اجتماعى و افسرد گى يرستاران همسو است. همجنين بخشى

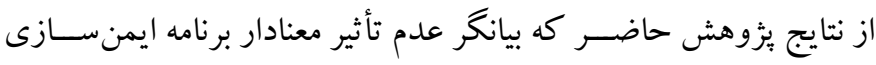

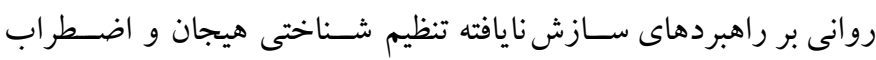

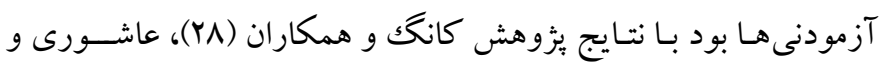

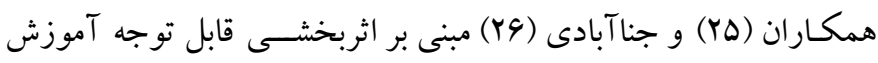

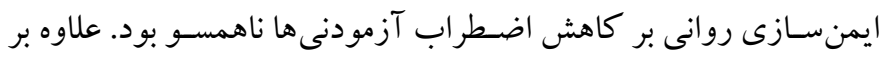

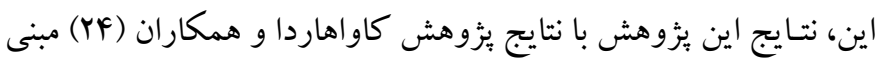

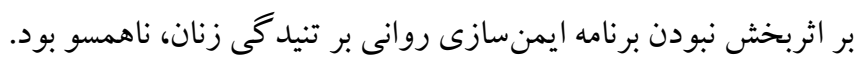

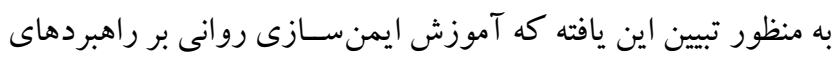

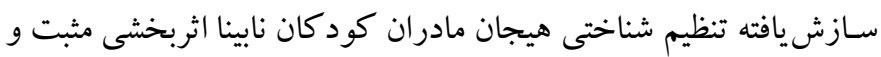

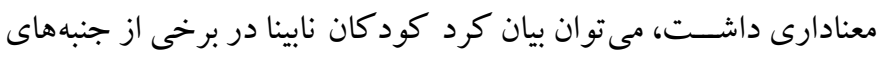

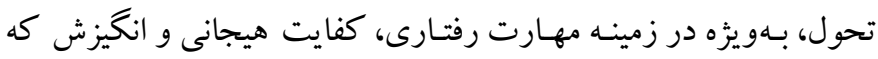

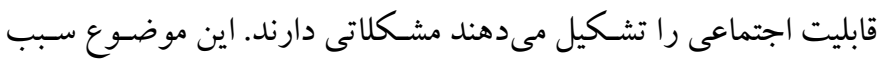

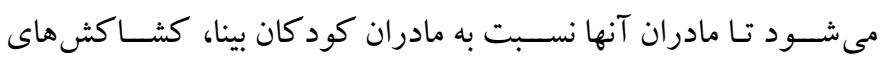
بيشـترى را تجربه كنند (F). همجنين، كود كان نابينا عملكرد ضسعيفى در رفتارهاى سازشى دارند. در بسيارى اوقات عامل اصلى، مشكلات آنها در

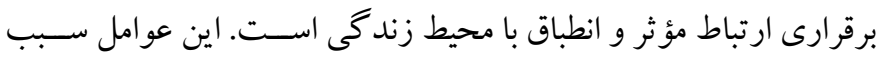

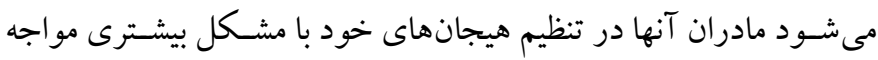

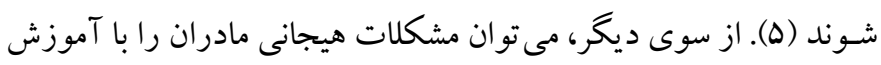

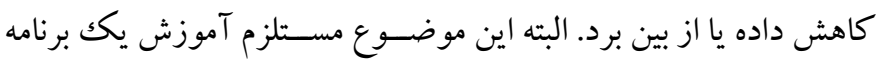

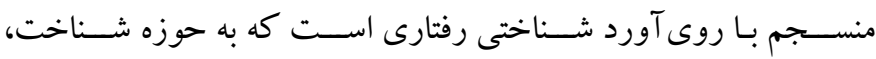

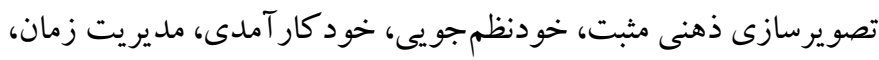

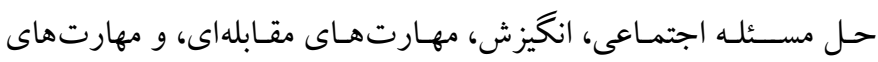

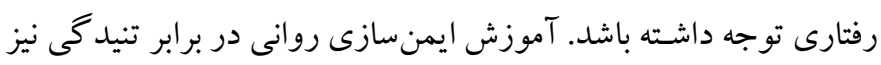

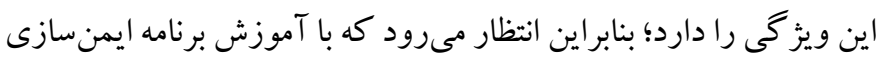
روانى در برابر تنيدگى بتوان تنظيم شـناختى هيجان مادران كود كان نابينا

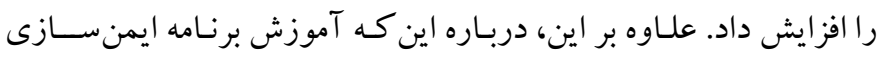

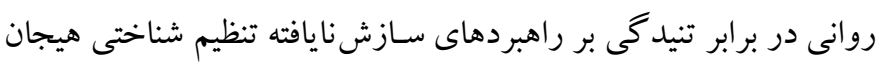

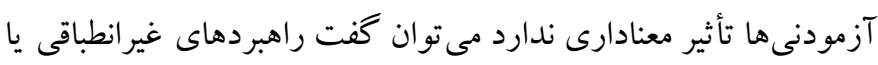

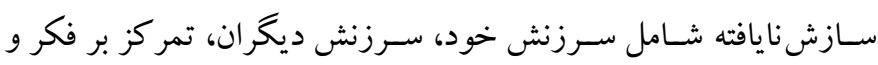

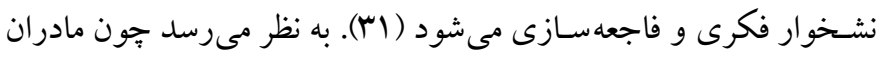

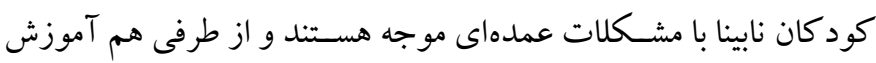


بودند كه دوران نوجوانى را سبرى كرده و مشكلات اجتماعى، اقتصادى

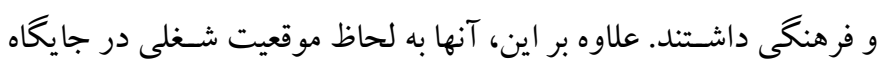

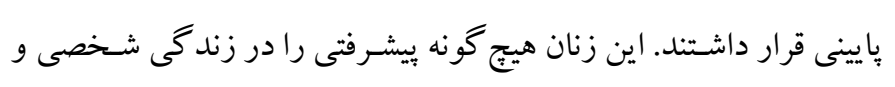

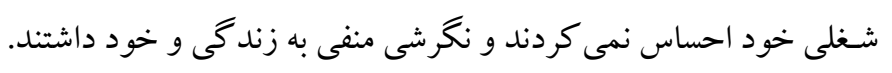

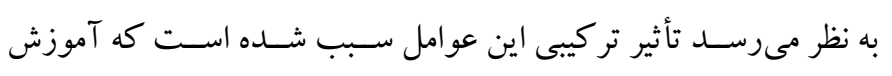

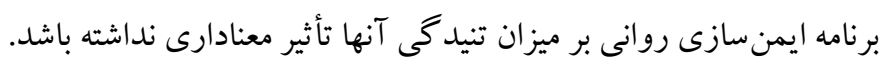

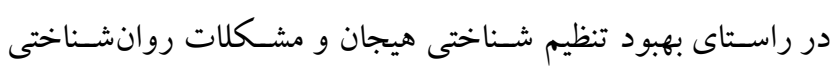

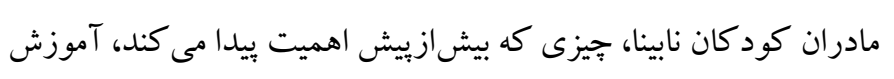

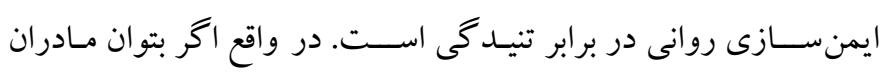

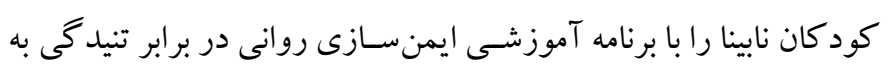
خوبى راهنمايى كرد، عوامـل تهديد كننده تنظيم شــناختى هيجان آنان

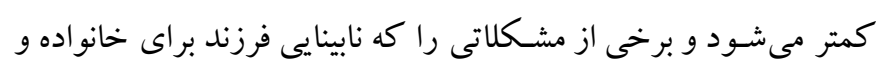

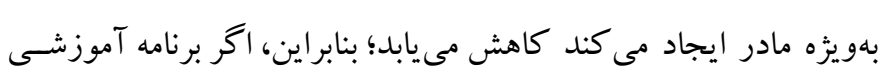

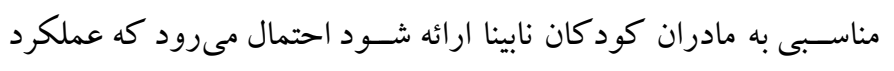

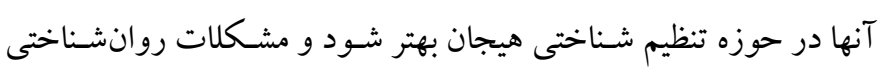

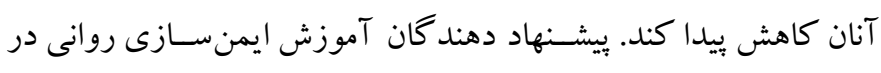

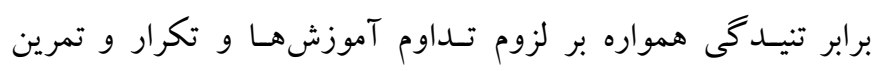

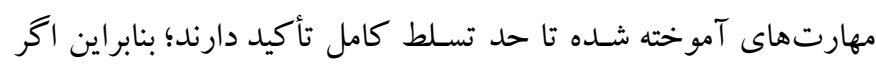

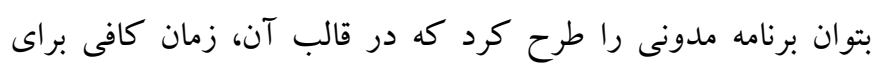

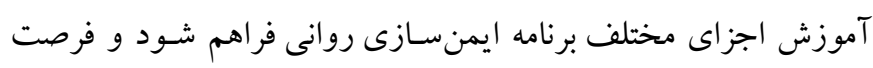

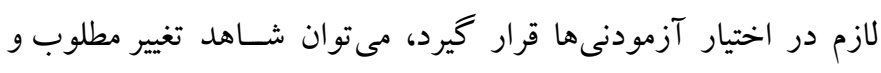

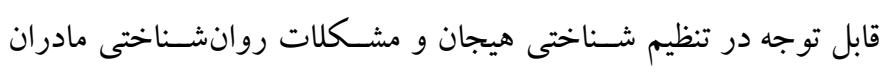

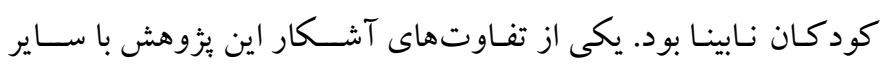

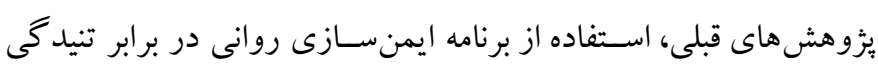

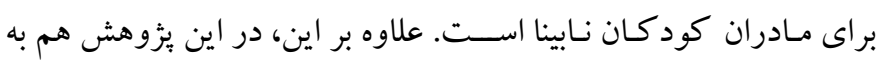
تنظيم شـاختى هيجان و هم به مشـكلات روانشناختى آزمودنى ها به طور

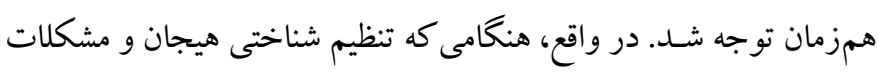

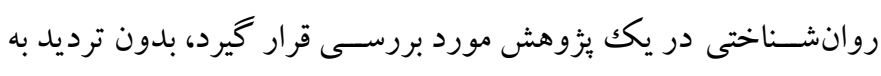

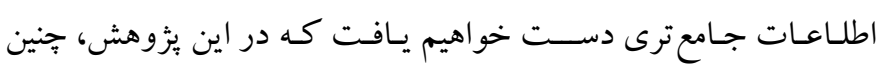

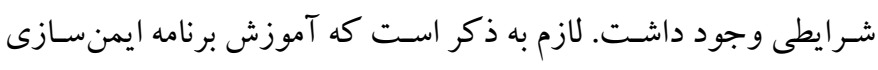

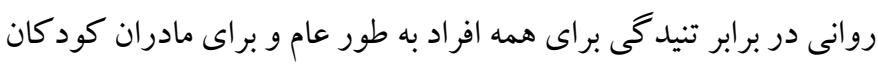

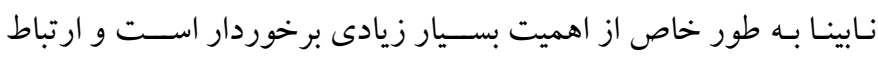

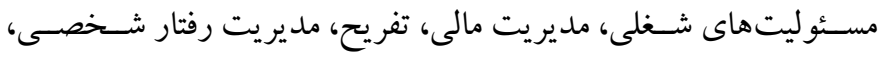

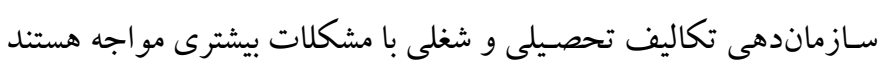

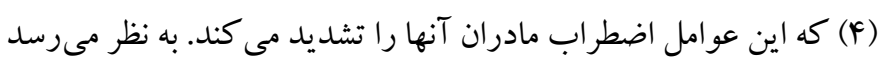

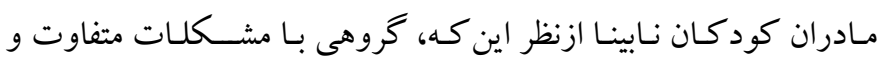

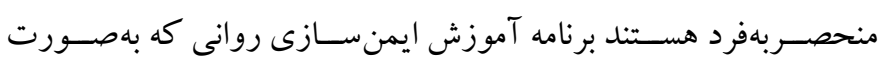

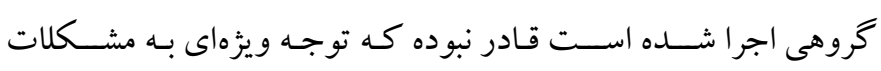

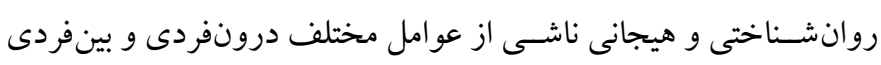

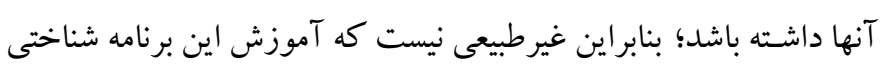
رفتارى موجب كاهش معنادار اضطراب مادران آنها نشود.

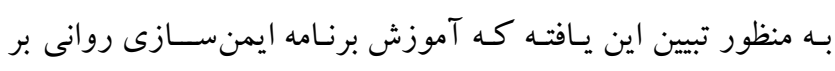

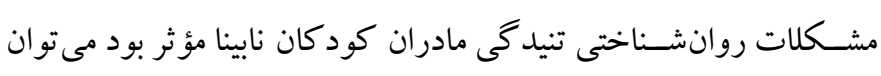

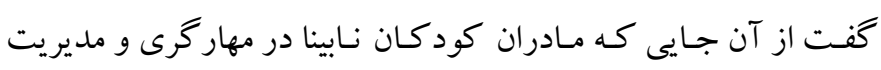

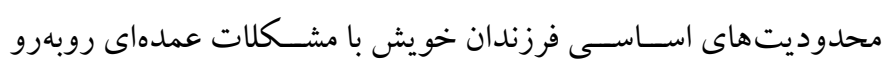

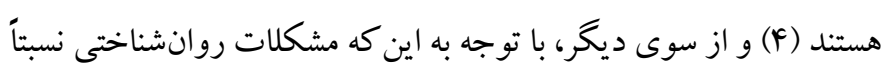

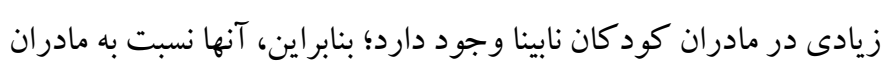

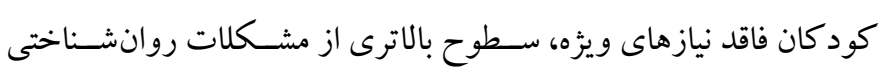

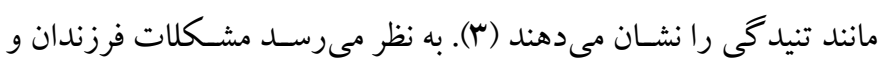

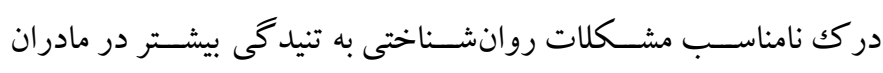
كود كان نابينا منجر شود. علاوه بر اين، احتمال مى رود جرخ مخه معيوبى ميان

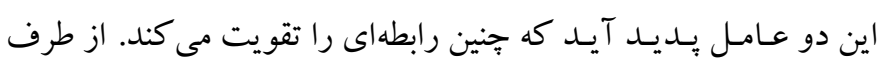

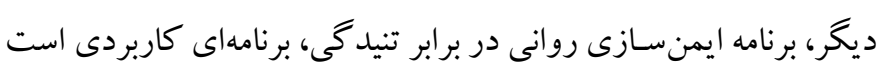

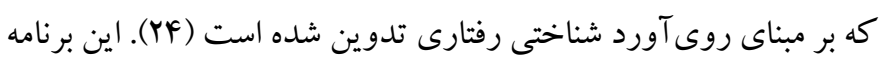

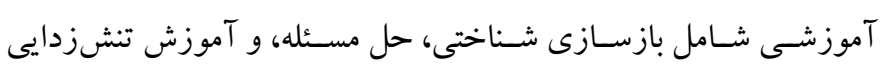
مىشـود. علاوه بر اين، آموزش ايمنس سـازى روانى سـبب تقويت انخيزش

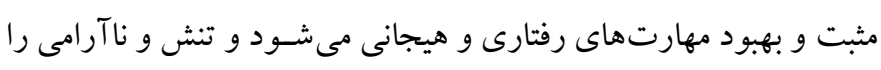

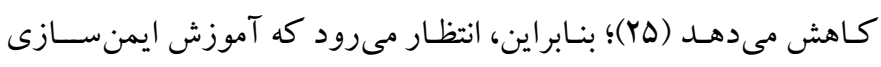
روانى موجب كاهش تنيدگى در مادران كود كان نابينا شود.

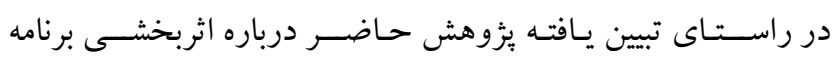

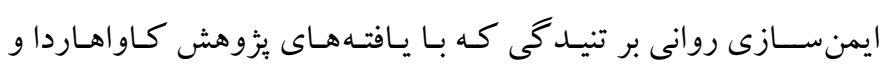

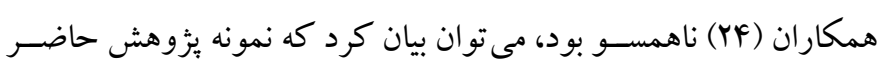

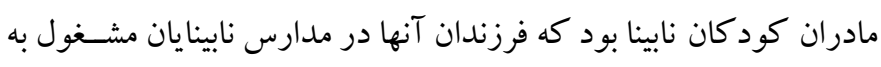

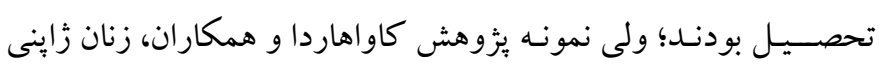


مى توان اطلاعات جامع ترى نسـبت به ميزان اثربخشـى اين آموزشها در طولانى مدت كسب كرد.

ملاحظات اخلاقى ييروى از اصسول اخلاق ثزوهش: مجوز اجراى اين مطالعه بر روى افراد نمونه از

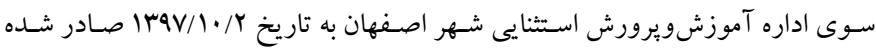

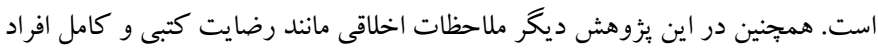
نمونه و رعايت اصل رازدارى و محر مانه ماندن اطلاعات، رعايت شده است.

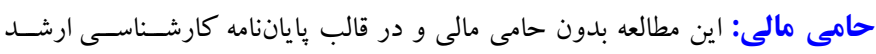
انجامشده است.

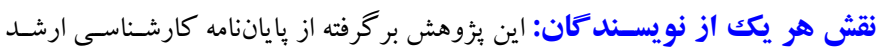

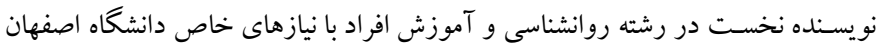

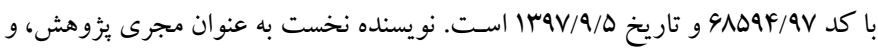
نويسنده دوم استاد راهنماى اين يزووهش بوده است.

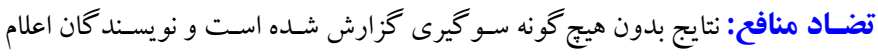
مى كنند كه هيج تضاد منافعى در يافتهاى حاضر وجود نداشته است.

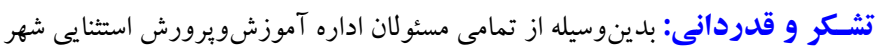
اصفهان به خصوص كارشناس بثزوهش كه هماهنكى با مدرسه جهت اجراى آموزش و يُّوهش را انجام دادند و همجينين از كادر ادارى و معلمان مدرسـه و افراد نمونه كه در برك اجراى اين يُوهش به ما كمك كردند، تشكر و قدردانى مى دشود.
نزديكى با تنظيم شـناختى هيجان و مشـكلات روانشـناختى آنها دارد. در واقـع برنـامـهـ ايمنســـازى روانى در برابر تنيـدكى يكى از مهم ترين برنامه هايى است كه توانست به تنظيم شناختى هيجان در مادران كود كان نابينا كمكك كند و مشكلات روانشناختى آنها را كاهش دهد. محسدوديتهايى كه اين بزوهش از نظر روششــاختى با آن مواجه بوده است، عبارتاند از: استفاده از ابزارها يا برسشنامههاى خود كزارشى، استفاده از طرح بثوهشى نيمه آزمايشى و شيوه نمونه گيرى در دسترس، و عدم اجراى آزمون بيخيرى به علت محدوديت زمانى. براى يثوهش هاى آتى بيشـنهاد مى شـود كه علاوه بر برسـشـنامه از مشـاهده و مصـاحبه هم

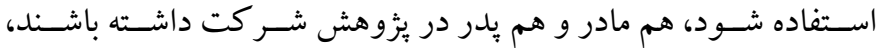
اثربخشسى برنامه مداخلاتى بر مادران كود كان نابينا با ميزان آسـيب بينايى متفـاوت و در دامنسه ســنى مختلف به روش انفر ادى مورد بررسـى قرار كيرد، از طرح بزوهشى آزمايشى و روش نمونه گيرى تصـادفى اسـتفاده شـود، در بررسى تنظيم شناختى هيجان و مشكلات روانشناختى به انواع برنـامـهــاى آموزشـى توجـه شــود، و تـأثير مـداخلات بر روى ســـاير ويز گیى هاى مادران كود كان نابينا در ســنين مختلف مورد بررسـى قرار كيرد. همجنين بـا در نظر كرفتن زمـانى جهـت اجراى آزمون بيكيرى 


\section{References}

1. Demmin DL, Silverstein SM. Visual impairment and mental health: Unmet needs and treatment options. Clin Ophthalmol. 2020; 14(1): 4229-4251. [Link]

2. Alnfiai M, Srinivas Sampalli S. Braille enter: A touch screen Braille text entry method for the Blind. The 8th International Conference on Ambient Systems, Networks and Technologies. Procedia Comput Sci. 2017; 109(1): 257-264. [Link]

3. Mohammad Yusef B, Sharifi Daramadi P, Aghaie H. The effect of body language and social skills training on social adjustment of students with visual impairment. J Child Ment Health. 2018; 5(2): 59-71. [Persian]. [Link]

4. Majerova $\mathrm{H}$. The person in a situation of visual impairment and its perception and imagination from the qualitative viewpoint. Procedia Soc Behav Sci. 2017; 237(1): 751-757. [Link]

5. Wettstein M, Spuling SM, Heyl V. Associations of self-reported vision problems with health and psychosocial functioning: A 9-year longitudinal perspective. British Journal of Visual Impairment. 2021; 39(1): 31-52. [Link]

6. Sepanta M, Abedi A, Yarmohammadian A, Ghomrani A, Faramarzi S. The effect of Frederickson's positive emotion training program on emotion regulation of students with dyslexia. J Child Ment Health. 2019; 5(4):94-109. [Persian]. [Link]

7. Hofmann SG, Carpenter JK, Curtiss J. Interpersonal emotion regulation questionnaire (IERQ): scale development and psychometric characteristics. Cogn Ther Res. 2016; 40(3): 341-356. [Link]

8. Tajaddini E, Sepehrianazar F, Soleymani E. Comparison of looming maladaptive style, negative problem-orientation, emotion regulation, and rejection sensitivity in the patients with AIDS and healthy people. RPH. 2018; 12(2): 53-67. [Persian]. [Link]

9. Moghaddam Poor N, Sepahvand T. The explanation of social anxiety in primary school children based on difficulties in emotional regulation and cognitive flexibility of mothers. J Child Ment Health. 2018; 5(2): 14-24. [Persian]. [Link]

10. Gregoire S, Lachance L. Taylor G. Mindfulness, mental health and emotion regulation among workers. I J W. 2015; 5(4): 96-119. [Link]

11. Alizadeh A, Kazemi Galogahi MH, Gamali Z, Barati M. Azizi M. The role of emotional regulation and spirituality on occupational stress in military nurses. NPWJM. 2014; 2(2):17-22. [Persian]. [Link]
12. Zaidman-Zait A, Most T, Tarrasch R, Haddad-eid E, Brand D. The impact of childhood hearing loss on the family: Mothers' and fathers' stress and coping resources. Journal Deaf Stud Deaf Educ. 2016; 21(1): 23-33. [Link]

13. Sadock BJ, Sadock VA. Kaplan \& Sadock's synopsis of psychiatry behavioral sciences clinical psychiatry. 10th edition. Philadelphia: Lippincott Williams \&Wilkins; 2007, pp: 167-169. [Link]

14. Hansenne M, Bianchi J. Emotional intelligence and personality in major depression: Trait versus state effects. Psychiatry Res. 2009; 166(1): 63-68. [Link]

15. Negovan V, Bagana E. A comparison of relationship between self-esteem and vulnerability to depression among high school and freshmen university students. Procedia Soc Behav Sci. 2011; 30(1): 1324-1330. Doi.org/10.1016/j.sbspro.2011.10.257 [Link]

16. Verhoeven M, Bogels SM, van der Bruggen CC. Unique roles of mothering and fathering in child anxiety; moderation by child's age and gender. J Child Fam Stud. 2012; 21(2): 331-343. [Link]

17. Esbjørn BH, Normann N, Christiansen BM, Reinholdt-Dunne, ML. The efficacy of group metacognitive therapy for children (MCT-c) with generalized anxiety disorder: An open trial. J Anxiety Disord. 2018; 53(1): 16-21. [Link]

18. Chen YA, Chan KCH, Liao PJ, Chen CK, Wu CM. Parental stress in raising mandarin-speaking children with cochlear implants. The Laryngoscope. 2013; 123(5): 1241-46. [Link]

19. Cooper CE, McLanahan SS, Meadows SO, BrooksGunn J. Family structure transitions and maternal parenting stress. J Marriage Fam. 2009; 71(3): 558-74. [Link]

20. Scrimin S, Haynes M, Altoe G, Bornstein MH, Axia G. Anxiety and stress in mothers and fathers in the 24 h after their child's surgery. Child Care Health Dev. 2009; 35(2): 227-233. [Link]

21. Ashori M, Pourmohamadreza-Tajrishi M, JalilAbkenar SS, Fallah AM, Azimi Garoosi S. Effectiveness of mental immunization program training on social competency and personality traits of individuals with cerebral palsy. Archives of Rehabilitation. 2017; 18(2): 98-109. [Persian]. [Link]

22. Sheehy R, Horan JJ. Effects of SIT for $1^{\text {st }}$ year law students. Int J Stress Manag. 2004; 11(1): 41-55. [Link]

23. Meichenbam D. Stress inoculation training: A preventative and treatment approach. $3^{\text {rd }}$ edition. Philadelphia: Guilford Press; 2007. pp: 84-89. [Link] 
24. Kawaharada M, Yoshioka E, Saijo Y, Fukui T, Ueno T, Kishi R. The effects of a stress inoculation training program for civil servants in japan: A pilot study of a non-randomized controlled trial. Ind Health. 2009; 47(2): 173-182. [Link]

25. Ashori M, Nakhostin N, Ghazaghi T. The effect of mental immunization training on psychological reactions and social competency of students with intellectual disability. J Child Ment Health. 2019; 5(4): 13-26. [Persian]. [Link]

26. Jenaabadi H. Survey on effectiveness of cognitivebehavioral stress management on mental health of mothers of children with developmental disorders, disruptive behavior disorders and cerebral palsy. RJMS. 2016; 23(148): 80-88. [Persian]. [Link]

27. Mazlom S, Darban F, Vaghei S, Modarres gharavi M, Kashani lotfabadi M, Shad M. The effect of stress inoculation program (SIP) on nurses' perceived stress in psychiatric wards. Evidence Based Care. 2012; 2(1): 35-44. [Persian]. [Link]

28. Kang YS, Choi SY, Ryu E. The effectiveness of a stress coping program based on mindfulness meditation on the stress, anxiety, and depression experienced by nursing students in Korea. Nurse Edu Today. 2009; 29(5): 538-543. [Link]
29. Esmaeili Z, Esmaeili L, Dabbashi F. Effectiveness of stress inoculation training on psychological wellbeing in women with diabetes mellitus type 2 . Int $\mathbf{J}$ Educ Psychol Res. 2016; 2(2): 88-93. [Persian]. [Link]

30. Garnefski N, Kraaij V. The cognitive emotion regulation questionnaire. European Journal of Psychological Assessment. 2007; 23(3): 141-149. [Link]

31. Besharat MA, Bazzazian S. Psychometri properties of the cognitive emotion regulation questionnaire in a sample of Iranian population. J Nurs \& Mid. 2015; 24(84): 61-70. [Persian]. [Link]

32. Ashori, M., Shojaei, S., Fatahian, F. Comparative study of depression, anxiety and stress between blind and normal individuals. Empowering Exceptional Children. 2017; 8(4): 71-80. [Persian]. [Link]

33. Antony MM, Bieling PJ, Cox BJ, Enns MW, Swinson RP. Psychometric properties of the 42-item and 21item versions of the depression anxiety stress scales in clinical groups and a community sample. Psychol Assess. 1998; 10(2): 176-181. [Link]

34. Samani S, Jokar B. Evaluate the reliability and validity of the short form of depression, anxiety and stress. J Social Sci Humanities Shiraz Univ. 2007; 26(3): 65-76. [Persian]. [Link] 